\title{
Thermal decomposition of tris(0-ethyldithiocarbonato)-antimony(III)—a single-source precursor for antimony sulfide thin films
}

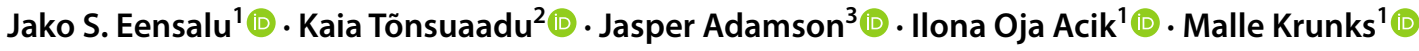

Received: 31 July 2020 / Accepted: 2 May 2021 / Published online: 20 June 2021

(c) The Author(s) 2021

\begin{abstract}
Thermal decomposition of tris(O-ethyldithiocarbonato)-antimony(III) (1), a precursor for $\mathrm{Sb}_{2} \mathrm{~S}_{3}$ thin films synthesized from an acidified aqueous solution of $\mathrm{SbCl}_{3}$ and $\mathrm{KS}_{2} \mathrm{COCH}_{2} \mathrm{CH}_{3}$, was monitored by simultaneous thermogravimetry, differential thermal analysis and evolved gas analysis via mass spectroscopy (TG/DTA-EGA-MS) measurements in dynamic Ar, and synthetic air atmospheres. 1 was identified by Fourier transform infrared spectroscopy (FTIR) and nuclear magnetic resonance (NMR) measurements, and quantified by NMR and elemental analysis. Solid intermediates and final decomposition products of $\mathbf{1}$ prepared in both atmospheres were determined by X-ray diffraction (XRD), Raman spectroscopy, and FTIR. 1 is a complex compound, where $\mathrm{Sb}$ is coordinated by three ethyldithiocarbonate ligands via the $\mathrm{S}$ atoms. The thermal degradation of 1 in Ar consists of three mass loss steps, and four mass loss steps in synthetic air. The total mass losses are 100\% at $800{ }^{\circ} \mathrm{C}$ in $\mathrm{Ar}$, and $66.8 \%$ at $600{ }^{\circ} \mathrm{C}$ in synthetic air, where the final product is $\mathrm{Sb}_{2} \mathrm{O}_{4} .1$ melts at $85^{\circ} \mathrm{C}$, and decomposes at 90-170 ${ }^{\circ} \mathrm{C}$ into mainly $\mathrm{Sb}_{2} \mathrm{~S}_{3}$, as confirmed by Raman, and an impurity phase consisting mostly of $\mathrm{CSO}_{2}^{2-}$ ligands. The solidphase mineralizes fully at $\approx 240{ }^{\circ} \mathrm{C}$, which permits $\mathrm{Sb}_{2} \mathrm{~S}_{3}$ to crystallize at around $250{ }^{\circ} \mathrm{C}$ in both atmospheres. The gaseous species evolved include $\mathrm{CS}_{2}, \mathrm{C}_{2} \mathrm{H}_{5} \mathrm{OH}, \mathrm{CO}, \mathrm{CO}_{2}, \mathrm{COS}, \mathrm{H}_{2} \mathrm{O}, \mathrm{SO}_{2}$, and minor quantities of $\mathrm{C}_{2} \mathrm{H}_{5} \mathrm{SH},\left(\mathrm{C}_{2} \mathrm{H}_{5}\right)_{2} \mathrm{~S},\left(\mathrm{C}_{2} \mathrm{H}_{5}\right)_{2} \mathrm{O}$, and $\left(\mathrm{S}_{2} \mathrm{COCH}_{2} \mathrm{CH}_{3}\right)_{2}$. The thermal decomposition mechanism of $\mathbf{1}$ is described with chemical reactions based on EGA-MS and solid intermediate decomposition product analysis.
\end{abstract}

Keywords Antimony ethyl xanthate $\cdot$ Thermal degradation $\cdot$ Evolved gas analysis $\cdot$ Antimony sulfide $\cdot$ Decomposition mechanism

\section{Introduction}

Antimony sulfide $\left(\mathrm{Sb}_{2} \mathrm{~S}_{3}\right)$ is a material naturally suitable for application as the absorber layer in thin film solar cells. The crustal abundance and price of $\mathrm{Sb}\left(0.2 \mathrm{ppm} ; \$ 8.6 \mathrm{~kg}^{-1}\right)$,

Jako S. Eensalu

jako.eensalu@taltech.ee

Malle Krunks

malle.krunks@taltech.ee

1 Laboratory of Thin Film Chemical Technologies, Department of Materials and Environmental Technology, Tallinn University of Technology, Ehitajate tee 5, 19086 Tallinn, Estonia

2 Laboratory of Inorganic Materials, Department of Materials and Environmental Technology, Tallinn University of Technology, Ehitajate tee 5, 19086 Tallinn, Estonia

3 Laboratory of Chemical Physics, National Institute of Chemical Physics and Biophysics, Akadeemia tee 23, 12618 Tallinn, Estonia and $\mathrm{S}$ (340 ppm; $\$ 0.05 \mathrm{~kg}^{-1}$ ), which form the nontoxic $\mathrm{Sb}_{2} \mathrm{~S}_{3}$, attest to its long-term economic viability as a strategic resource [1-3]. The anisotropic $\mathrm{Sb}_{2} \mathrm{~S}_{3}$ has a bandgap of $\approx 1.7 \mathrm{eV}$, a high absorption coefficient of $1 \cdot 10^{5} \mathrm{~cm}^{-1}$ at $450 \mathrm{~nm}$, a melting point of $550{ }^{\circ} \mathrm{C}$, and is stable toward moisture, $\mathrm{UV}$, and oxidation in air below $150{ }^{\circ} \mathrm{C}$, being etched only by concentrated acid [4-7]. A bandgap of $1.7 \mathrm{eV}$ makes $\mathrm{Sb}_{2} \mathrm{~S}_{3}$ a prime candidate for application as the top cell absorber in tandem solar cells [8, 9], and as the thinner than $200 \mathrm{~nm}$ absorber in IR inactive semitransparent solar cells $[10,11]$.

$\mathrm{Sb}_{2} \mathrm{~S}_{3}$ thin films have been fabricated from colloidal or metal-organic precursors by a number of solution-based 
chemical methods, e.g., chemical bath (CBD) [12-14], atomic layer deposition (ALD) [15-17], spin-coating [18, 19], spray pyrolysis [11, 20-22], and by physical methods, e.g., thermal evaporation (TE) from inorganic targets [23], mainly for application as absorber in thin film solar cells. The highest power conversion efficiency achieved for planar $\mathrm{Sb}_{2} \mathrm{~S}_{3}$ thin film solar cell is $6.6 \%$ by spin-coating a metal-organic complex of $\mathrm{Sb}$, followed by annealing and Cs-doping [19], whereas the top power conversion efficiency of $\mathrm{Sb}_{2} \mathrm{~S}_{3}$ solar cells is $7.5 \%$ [24]. Mass production of $\mathrm{Sb}_{2} \mathrm{~S}_{3}$ solar cells with consistent power conversion efficiency requires use of simple and cost-effective methods, e.g., spray pyrolysis, as other methods are likely too expensive (vacuum, inert gas, specialty reagents for ALD, TE), too time consuming and waste-generating (CBD), or too smallscale (spin-coating) [25].

In order to fabricate $\mathrm{Sb}_{2} \mathrm{~S}_{3}$ thin films from organometallic precursors, it is crucial to understand their decomposition mechanisms in oxidizing and inert atmosphere. Our laboratory has experience in analysis of formation of $\mathrm{CuS}$, $\mathrm{In}_{2} \mathrm{~S}_{3}, \mathrm{CuInS}_{2}, \mathrm{ZnS}$, and $\mathrm{SnS}$ thin films by employing TG/ DTA-EGA for thiourea-based precursors to estimate the appropriate deposition conditions for spray pyrolysis in air [26-31]. The resulting thin films contained $\mathrm{C}$ and $\mathrm{Cl}$ impurities, except in case of $\mathrm{Sb}_{2} \mathrm{~S}_{3}$, where uniform thin films of $\mathrm{Sb}_{2} \mathrm{~S}_{3}$, free of $\mathrm{C}$ and $\mathrm{Cl}$ to detectable limits, were deposited at $210^{\circ} \mathrm{C}$ by spray pyrolysis, wherein a liquid-phase reaction occurred due to a favorably low melting point of the precursors [22]. As lowering the deposition and annealing temperature of $\mathrm{Sb}_{2} \mathrm{~S}_{3}$ thin films is critical for application as the $\approx 1.7 \mathrm{eV}$ top absorber in tandem solar cells, the processing temperature must be decreased further. Moreover, lower processing temperature and shorter processing time would decrease the energy budget, ergo, the cost of producing $\mathrm{Sb}_{2} \mathrm{~S}_{3}$ thin film-based solar cells and other devices, and increase the selection of usable substrates.

Metal xanthates, i.e., alkoxy- or aryldithiocarbonates, tend to decompose at low temperatures $\left(100-250{ }^{\circ} \mathrm{C}\right)[32$, 33], which is suitable to deposit metal chalcogenide thin films onto polymer substrates for flexible applications, and to fabricate the top cell for tandem solar cells. However, the decomposition mechanism and temperature of each xanthate depend significantly on the combination of cation [34], and ligand [33], meaning that TG/DTA-EGA could be of use. Xanthates, e.g., potassium ethyl xanthate $\left(\mathrm{KS}_{2} \mathrm{COCH}_{2} \mathrm{CH}_{3}\right.$, KEX) were discovered by W. C. Zeise in 1822 [4]. Since then, xanthates and related organometallic compounds are being used in ore flotation, in organic chemistry, in analytical chemistry, in biochemistry, in coordination chemistry, and in materials science to fabricate metal chalcogenide powders and layers, e.g., $\mathrm{ZnS}, \mathrm{NiS}, \mathrm{Fe}_{2} \mathrm{~S}_{3}, \mathrm{Cu}_{2} \mathrm{~S}, \mathrm{PbS}, \mathrm{As}_{2} \mathrm{~S}_{3}, \mathrm{Sb}_{2} \mathrm{~S}_{3}$, $\mathrm{Bi}_{2} \mathrm{~S}_{3}$, and lead-free perovskites [4, 32, 34-44]. Antimony ethyl xanthate (SbEX) has risen to prominence in the last decade as a single-source precursor to fabricate $\mathrm{Sb}_{2} \mathrm{~S}_{3}$ powders for various applications, or to make porous layers for use as the absorber in solar cells by solution-based chemical methods, e.g., solvothermal, or spin-coating coupled with post-deposition annealing at $160-240{ }^{\circ} \mathrm{C}[33,39,45]$.

A comprehensive thermal decomposition study of SbEX, where TG/DTA is coupled with evolved gas analysis and intermediate solid decomposition product analysis, has not been published. Sporadic studies of TG curves of SbEX have been published with contradictory and vague statements regarding the temperature required to produce phase pure $\mathrm{Sb}_{2} \mathrm{~S}_{3}[32,33,39,45]$. Therefore, a comparative study of the TG/DTA-EGA-MS of SbEX in inert and oxidizing atmosphere is required to determine its suitability for depositing phase pure $\mathrm{Sb}_{2} \mathrm{~S}_{3}$ thin films for application in semitransparent, bifacial, and as the top cell absorber in tandem solar cells, in addition to other semiconductor applications.

Aiming to determine the viability of SbEX as a singlesource precursor for depositing $\mathrm{Sb}_{2} \mathrm{~S}_{3}$ thin films by ultrasonic spray pyrolysis, we investigate the thermal decomposition of SbEX in inert and synthetic air atmosphere in this study by TG/DTA-EGA-MS coupled with analysis of the solid intermediate decomposition products of SbEX, and describe the mechanism of thermal decomposition of SbEX.

\section{Experimental}

\section{Synthesis}

Potassium ethyldithiocarbonate (potassium ethyl xanthate, KEX) (>97 mass\%, Acros) and antimony(III)chloride $\left(\mathrm{SbCl}_{3}\right)$ (99 mass\%, Sigma-Aldrich), deionized water $\left(18.2 \mathrm{M} \Omega \mathrm{cm}^{-1}\right)$, and $\mathrm{HCl}(\geq 37 \mathrm{vol} \%$, Sigma-Aldrich) were employed for the synthesis of the precursor for thermal analysis. All chemicals were used as-bought without further purification. The precursor for thermal analysis was synthesized according to the literature [40], with some modifications.

The precursor was synthesized at room temperature by pouring $375 \mathrm{mM}$ of KEX to $200 \mathrm{~mL}$ of $125 \mathrm{mM} \mathrm{SbCl}_{3}$, acidified beforehand with $\mathrm{HCl}$ to retain $\mathrm{SbCl}_{3}$, while stirring. A bright yellow substance started precipitating immediately upon mixing. The solution was stirred for $60 \mathrm{~min}$. The precipitate was rinsed with deionized water, diethyl ether (99.5 vol\%, Sigma-Aldrich), and acetone (99.8 vol\%, Merck), then recrystallized from acetone and rinsed with water at $83 \%$ yield. This product, named $\mathbf{1}$ going forward, was used for further analysis. 


\section{Elemental analysis}

The elemental composition of $\mathbf{1}$ was analyzed by energydispersive X-ray spectroscopy (EDX) on a Zeiss Ultra 55 FEG HR-SEM setup equipped with a Bruker ESPRIT 1.8 system. The atomic ratio of $\mathrm{S} / \mathrm{Sb}$ was found to be $5.7 \pm 0.1$, which is $93-97 \%$ of the expected stoichiometric atomic ratio of $\mathrm{S}$ to $\mathrm{Sb}$ of 6.0 in SbEX.

\section{Nuclear magnetic resonance analysis}

The nuclear magnetic resonance (NMR) analysis was carried out on a $800 \mathrm{MHz}$ Bruker Avance III setup connected with a $18.8 \mathrm{~T}$ magnet/ $54 \mathrm{~mm}$ heat opening diameter at $25^{\circ} \mathrm{C}$. Samples of $\mathbf{1}$ were weighed, and dissolved in $\mathrm{CDCl}_{3}(99.8$ vol\%, Eurisotop) for $1 \mathrm{D}$ qualitative ${ }^{1} \mathrm{H}, 1 \mathrm{D}$ quantitative ${ }^{13} \mathrm{C}$, 2D homonuclear correlation spectroscopy (COSY), heteronuclear single-quantum correlation spectroscopy (HSQC), and heteronuclear multiple-bond correlation spectroscopy (HMBC) NMR. For 1D quantitative ${ }^{1} \mathrm{H}$ analysis, $\mathbf{1}$ and 2-Propanol (99.9 vol\%, Sigma-Aldrich) were weighed in a fixed molar ratio on a microbalance after antistatic screening, and co-dissolved in $\mathrm{CD}_{3} \mathrm{OD}(\mathrm{MeOD}, 99.8 \mathrm{vol} \%$, Eurisotop). Chemical shifts in ppm were calibrated relative to $\mathrm{CDCl}_{3}$ and $\mathrm{MeOD}$. The residual mass of $\mathbf{1}$ in the weighing tray was subtracted before quantification. NMR data were analyzed, and figures were generated using Mestrelab MNova software.

\section{Vibrational analysis}

The FTIR spectra of KEX and $\mathbf{1}$ were measured on a FTIR setup (Perkin Elmer GX 2000), 400-4000 $\mathrm{cm}^{-1}, 4 \mathrm{~cm}^{-1}$ resolution, 32 scans, by the $\mathrm{KBr}$ pellet method, using the FTIR spectrum of the $\mathrm{KBr}$ pellet as background. 1.0 mass\% of sample per $200 \mathrm{mg}$ of $\mathrm{KBr}$, pre-dried in air at $150{ }^{\circ} \mathrm{C}$ for $1 \mathrm{~h}$, was pressed into a $13 \mathrm{~mm}$-diameter pellet after grinding the mixture with a corundum pestle and mortar.

The FTIR spectra of $\mathbf{1}$, and its intermediate decomposition products prepared at $115^{\circ} \mathrm{C}$, and at $160{ }^{\circ} \mathrm{C}$ in flowing $\mathrm{N}_{2}$, and air were measured on a Bruker Alpha FTIR setup, equipped with a diamond anvil in absorptance mode, 24 scans, resolution $4 \mathrm{~cm}^{-1}$.

In addition, Raman spectra of $\mathbf{1}$ and its intermediate solid decomposition products were measured on a micro-Raman setup (Horiba LabRam 800, $15 \mu \mathrm{W} \mu \mathrm{m}^{-2}, 532 \mathrm{~nm}$ He-Ne, $\varnothing$ $5 \mu \mathrm{m}$ ), calibrated with $546.1 \mathrm{~nm} \mathrm{Hg}$ line. Raman data were analyzed with Fityk software [46]. FTIR and Raman figures were generated with OriginLab software.

\section{Thermal analysis}

The simultaneous TG/DTA/EGA-MS measurement of $\mathbf{1}$ was performed in a Setaram LabSys EVO apparatus, using a heating rate of $10{ }^{\circ} \mathrm{C} \mathrm{min}^{-1}$, purge gas (Ar or $80 \% \mathrm{Ar}$, $20 \% \mathrm{O}_{2}$-synthetic air) with a flow rate of $60 \mathrm{~mL} \mathrm{~min}^{-1}$, sample mass $14.2 \mathrm{mg}$ (in $\mathrm{Ar}$ ), and $13.5 \mathrm{mg}$ (in synthetic air) in open $\mathrm{Al}_{2} \mathrm{O}_{3}$ crucible. The gaseous species were guided into a ThermoStar GSD320 quadrupole mass spectrometer through a heated capillary tube kept at $180^{\circ} \mathrm{C}$. Data were collected in multiple ion detection mode (MID) monitoring 21 channels between $\mathrm{m} / \mathrm{z}=1-89$. Collection time was $1 \mathrm{~s}$ for each channel. EGA-MS figures were generated with OriginLab software.

The evolved gases were identified based on their MS reference spectra available in the public domain spectral library of NIST [47]. Reaction schemes were generated with ACD ChemSketch freeware.

\section{Intermediate decomposition product preparation}

Intermediate decomposition products of $\mathbf{1}$ were prepared in inert atmosphere in laboratory test as follows: after purging the quartz tube inside the two-zone tube furnace to $1 \cdot 10^{-3}$ mbar at room temperature, $99.999 \% \mathrm{~N}_{2}$ flow of $60 \mathrm{~mL} \mathrm{~min}{ }^{-1}$, and heating rate of $10{ }^{\circ} \mathrm{C} \mathrm{min}^{-1}$ were used, while retaining the ceramic crucible at $170{ }^{\circ} \mathrm{C}, 270{ }^{\circ} \mathrm{C}$, $400{ }^{\circ} \mathrm{C}$, or $730{ }^{\circ} \mathrm{C}$ for 10 min before cooling in ambient to $\approx 40{ }^{\circ} \mathrm{C}$ and withdrawing. Intermediate decomposition products of $\mathbf{1}$ in air were prepared in laboratory test at $170{ }^{\circ} \mathrm{C}, 270{ }^{\circ} \mathrm{C}$, and $480{ }^{\circ} \mathrm{C}$ by inserting 1 into a preheated muffle furnace, and retaining the specified temperature in the crucible for $10 \mathrm{~min}$ before withdrawing. At $600{ }^{\circ} \mathrm{C}$, the residue from TG/DTA in synthetic air was used.

For FTIR analysis of the products of the first decomposition step, intermediate decomposition products of $\mathbf{1}$ were prepared in inert atmosphere in the same two-zone tube furnace as follows: after purging to $1 \cdot 10^{-3} \mathrm{mbar}$ at room temperature, $99.999 \% \mathrm{~N}_{2}$ flow of $30 \mathrm{~mL} \mathrm{~min}^{-1}$, and heating rate of $5{ }^{\circ} \mathrm{C} \mathrm{min}^{-1}$ were used, while retaining the crucible at $115^{\circ} \mathrm{C}$, or $160{ }^{\circ} \mathrm{C}$ for 3 min before cooling in ambient to $\approx 40{ }^{\circ} \mathrm{C}$ and withdrawing. For FTIR analysis of the first decomposition step, intermediate decomposition products of $\mathbf{1}$ in air were prepared as follows: $\mathbf{1}$ was inserted into a preheated muffle furnace and heated in a semi-closed crucible, to prevent the solid from surging out, at the specified temperature for 3 min before withdrawal, and immediately cooled in a cold water bath to room temperature. 


\section{Structural analysis}

The phase composition of $\mathbf{1}$, its intermediate and final decomposition products were analyzed with a powder XRD (Rigaku Ultima IV, Si strip detector D/teX Ultra), $\mathrm{Cu} \mathrm{K} \mathrm{K}_{\alpha 1} \lambda$ $1.5406 \AA$ А $\theta-2 \theta$ mode, $5^{\circ} \mathrm{min}^{-1}$, step $0.02^{\circ}, 40 \mathrm{kV}, 40 \mathrm{~mA}$. XRD data were analyzed using Rigaku PDXL 2 software. Figures were generated with OriginLab software.

\section{Results and discussion}

\section{Identification of 1}

The FTIR spectra of potassium ethyl xanthate $\left(\mathrm{KS}_{2} \mathrm{COC}_{2} \mathrm{H}_{5}-\mathrm{KEX}\right)$ and antimony ethyl xanthate $\left(\mathrm{Sb}\left(\mathrm{S}_{2} \mathrm{COC}_{2} \mathrm{H}_{5}\right)_{3}-\mathrm{SbEX}\right)$ have been published before, being only presented in this study to identify and demonstrate the purity of KEX and 1. FTIR spectra of KEX and 1, as measured by the $\mathrm{KBr}$ technique, are shown in Fig. 1. The list of possible assignments of FTIR bands of KEX and $\mathbf{1}$, based on the literature [36, 38, 41-43, 48, 49], is presented in Table S1 in the electronic Supporting File.

According to FTIR, the spectra of KEX and $\mathbf{1}$ were similar, although bands had shifted in the range of $1300 \mathrm{~cm}^{-1}-1000 \mathrm{~cm}^{-1}$ in 1 vs KEX, showing that the complex with $\mathrm{Sb}$ seems to have formed. The $\mathrm{C}=\mathrm{S}$ stretching modes shifted from $1006 \mathrm{~cm}^{-1}$ and $1050 \mathrm{~cm}^{-1}$ in KEX to $1001 \mathrm{~cm}^{-1}$, and $1024 \mathrm{~cm}^{-1}$ in $\mathbf{1}$, indicating the formation of longer $\mathrm{C}-\mathrm{S}$ bonds as a result of the stronger electron pull toward $\mathrm{Sb}$ in the $\mathrm{Sb}-\mathrm{S}$ bond than in the K-S bond due to $\mathrm{Sb}$ being more electronegative than $\mathrm{K}$. The symmetric $\mathrm{C}-\mathrm{O}-\mathrm{C}$ stretching $\left(1103 \mathrm{~cm}^{-1}, 1118 \mathrm{~cm}^{-1}\right)$ in KEX, shifted to $1112 \mathrm{~cm}^{-1}$, and $1135 \mathrm{~cm}^{-1}$ in $\mathbf{1}$. The asymmetric $\mathrm{C}-\mathrm{O}-\mathrm{C}$ stretching $\left(1158 \mathrm{~cm}^{-1}, 1173 \mathrm{~cm}^{-1}\right)$ in KEX, merged into a strong band at $1230 \mathrm{~cm}^{-1}$ in 1 . $\mathrm{C}-\mathrm{O}-\mathrm{C}$ stretching modes shifting to higher wavenumbers likely points to a shortening of $\mathrm{C}-\mathrm{O}-\mathrm{C}$ bonds in the ligand. Weaker bands appearing at $3000-2870 \mathrm{~cm}^{-1}, 1468 \mathrm{~cm}^{-1}, 1448 \mathrm{~cm}^{-1}, 1075 \mathrm{~cm}^{-1}$ and $813 \mathrm{~cm}^{-1}$ attributed to $\mathrm{CH}_{3}$ and $\mathrm{CH}_{2}$ stretching and bending modes did not shift considerably, revealing that the interaction between the ethyl group and the cation $(\mathrm{K}$, $\mathrm{Sb}$ ) is weak, as expected. Therefore, the ethyl group is the farthest, and the $\mathrm{CS}_{2}$ group is probably the closest to $\mathrm{Sb}$, connected to each other by the $\mathrm{C}-\mathrm{O}-\mathrm{C}$ bridge. The wide band positioned at $3650-3300 \mathrm{~cm}^{-1}$ in both KEX and 1 is attributed to adsorbed $\mathrm{H}_{2} \mathrm{O}$.

The Raman spectrum of $\mathbf{1}$ is shown in Fig. S1. So far, the Raman spectrum of SbEX is unindexed, though 35 Raman active optical modes in the range of $50-3000 \mathrm{~cm}^{-1}$ were observed in the Raman spectrum of $\mathbf{1}$. The most intense Raman bands of $\mathbf{1}$ are centered at 91, 167, 232, 339, 406, $439,665,845,998$, and $1029 \mathrm{~cm}^{-1}$. Raman band centers of $\mathbf{1}$, with possible assignments from compounds similar to SbEX [43, 48, 50], are listed in Table S2. Raman bands attributed to only $\mathbf{1}$ were found above the limit of detection.

The crystal structure of SbEX is rhombohedral, space group $\mathrm{R} \overline{3}, a=10.13 \AA$, $\alpha=103^{\circ} 30^{\prime}$, six units in the unit cell, and each $\mathrm{Sb}$ atom is known to be surrounded by three $\mathrm{S}$ atoms at $2.52 \AA$, and another three at $3.00 \AA$, which altogether form a distorted octahedron, extending into the planar $\mathrm{S}_{2} \mathrm{C}-\mathrm{O}$ group [51, 52]. The XRD pattern of rhombohedral $\mathrm{SbEX}$ is available in the CSD database under SBXANT, and the XRD pattern of $\mathbf{1}$ is presented only to confirm its identity as SbEX (Fig. S2, numeric data in Table S3). According to $\mathrm{XRD}$, additional phases above the limit of detection were not found in $\mathbf{1}$.

The 1D NMR analysis results are presented in Table 1. Minor traces of acetone and ethanol were found in 1. Evidently, the acquired ${ }^{1} \mathrm{H}$ and ${ }^{13} \mathrm{C}$ NMR data correspond to
Fig. 1 FTIR spectra of potassium ethyl xanthate (KEX) and 1 recorded with $4 \mathrm{~cm}^{-1}$ resolution in $\mathrm{KBr}$ pellet

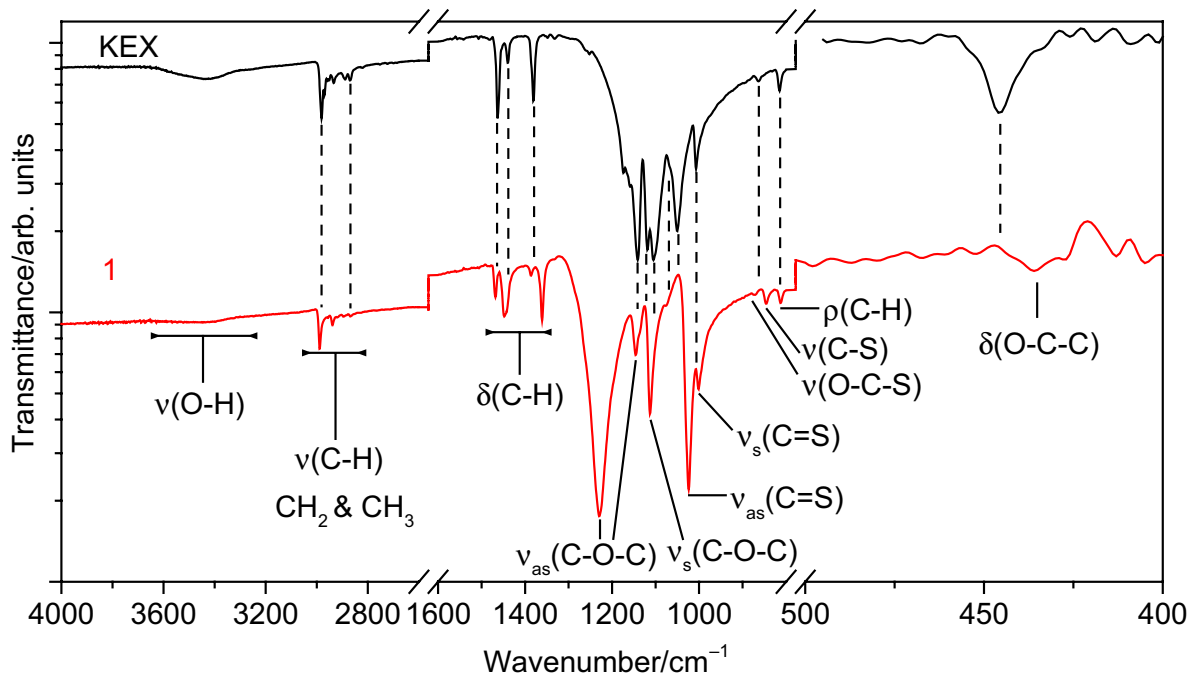


Table $1{ }^{1} \mathrm{H}$ and ${ }^{13} \mathrm{C}$ spectral data of $\mathbf{1}$ in comparison to the literature $[33,53]$

\begin{tabular}{|c|c|c|c|c|c|c|c|c|c|}
\hline \multirow[t]{2}{*}{ Compound } & \multicolumn{2}{|l|}{${ }^{1} \mathrm{H} / \mathrm{ppm}$} & \multirow[b]{2}{*}{ Ref } & \multicolumn{2}{|l|}{${ }^{13} \mathrm{C} / \mathrm{ppm}$} & \multirow[b]{2}{*}{ Ref } & \multicolumn{2}{|c|}{ Integral of ${ }^{1} \mathrm{H}$} & \multirow[t]{2}{*}{ Functional group } \\
\hline & Found in $\mathbf{1}$ & Literature & & Found in $\mathbf{1}$ & Literature & & 1 & 2-PrOH & \\
\hline $\mathrm{CDCl}_{3}$ & $7.26, \mathrm{~s}$ & 7.26 & {$[53]$} & 77.16 & 77.16 & {$[53]$} & - & - & $\mathrm{CHCl}_{3}$ \\
\hline $\mathrm{CH}_{3} \mathrm{COCH}_{3}$ & $2.17, \mathrm{~s}$ & 2.17 & {$[53]$} & - & 30.92 & [53] & - & 0.01 & $-\mathrm{CH}_{3}$ \\
\hline \multirow[t]{2}{*}{ 2-PrOH } & $1.20, \mathrm{~d}$ & 1.22 & {$[53]$} & 25.48 & 25.14 & {$[53]$} & - & 6.26 & $-\mathrm{CH}_{3}$ \\
\hline & 4.01, sept & 4.04 & [53] & 64.53 & 64.50 & {$[53]$} & - & 1.00 & $-\mathrm{CH}-$ \\
\hline \multirow[t]{3}{*}{1} & $1.47, \mathrm{t}$ & 1.40 & [33] & 14.00 & 12.40 & [33] & 3.00 & 4.18 & $-\mathrm{CH}_{3}$ \\
\hline & $4.64, \mathrm{q}$ & 4.55 & [33] & 72.17 & 71.00 & [33] & 2.00 & $2.15^{\mathrm{a}}$ & $-\mathrm{CH}_{2-}^{-}$ \\
\hline & - & & & 222.60 & 221.40 & [33] & - & - & $-\mathrm{O}-\mathrm{C}-\mathrm{S}_{2}$ \\
\hline
\end{tabular}

${ }^{a}$ The $\mathrm{CH}_{2}$ functional group was used to calculate the purity of $\mathbf{1}$ with respect to the known amount of 2-PrOH. There was overlap between the signals for the $\mathrm{CH}_{3}$ functional group of 2-PrOH and the $\mathrm{CH}_{3}$ functional group of $\mathbf{1}$, which prevented accurate integration of these proton peaks

Table 2 COSY, HSQC and HMBC spectral data of 1

\begin{tabular}{lllll}
\hline Method & ${ }^{1} \mathrm{H} / \mathrm{ppm}$ & & ${ }^{13} \mathrm{C} / \mathrm{ppm}$ & Functional groups \\
\hline COSY & 1.43 & 4.65 & - & $-\mathrm{CH}_{2}-\mathrm{CH}_{3}$ \\
& 4.60 & 1.48 & - & \\
HSQC & 1.46 & & 14.04 & $-\mathrm{CH}_{3}$ \\
& 4.64 & & 72.16 & $-\mathrm{CH}_{2}-$ \\
HBMC & 4.64 & & 14.04 & $-\mathrm{CH}_{2}-\mathrm{CH}_{3}$ \\
& 1.46 & & 72.16 & $-\mathbf{C H}_{2}-\mathrm{CH}_{3}$ \\
& 4.64 & & 222.60 & $\mathrm{~S}_{2}-\mathbf{C}-\mathrm{O}-\mathrm{CH}_{2-}$ \\
\hline
\end{tabular}

${ }^{\mathrm{a}} \mathrm{HMBC}$ correlated nuclei are in bold

relevant values in the literature $[33,53]$, thereby complementing the FTIR data in identification of $\mathbf{1}$.

According to quantitative ${ }^{1} \mathrm{H}$ of $\mathrm{CH}_{3}$, the analyte contained the equivalent of $95 \mathrm{~mol} \%$ of $(\mathrm{EX})_{3}$ versus $2-\mathrm{PrOH}$ (Table 1). The remaining $5 \mathrm{~mol} \%$ of 1 precipitated in the NMR test tube. According to XRD, the red precipitate was amorphous, as no reflections were observed. The Raman spectrum of the precipitate contained a single broad band, stretching from $200-360 \mathrm{~cm}^{-1}$, and centered at $290 \mathrm{~cm}^{-1}$, characteristic of amorphous $\mathrm{Sb}_{2} \mathrm{~S}_{3}$ [21, 22]. Thus, the results of quantitative NMR, XRD, and Raman support the observations made in EDX analysis of $\mathbf{1}$ regarding its slight deficiency of sulfur ( $\mathrm{S} / \mathrm{Sb}$ of 1.42) vs stoichiometric composition of $\mathrm{S} / \mathrm{Sb}$ of 1.50. Indeed, it is known that SbEX can change from light yellow to dark yellow, then to orange by decomposing over time to amorphous $\mathrm{Sb}_{2} \mathrm{~S}_{3}$ [36].

Based on the liquid NMR COSY analysis (Table 2), 1 contains mutually J-bonded $\mathrm{CH}_{3}$ and $\mathrm{CH}_{2}$ groups. HSQC analysis revealed that the two observed peaks at $\left({ }^{1} \mathrm{H} 1.46\right.$; $\left.{ }^{13} \mathrm{C} 14.04\right)$ and $\left({ }^{1} \mathrm{H} 4.64 ;{ }^{13} \mathrm{C} 72.16\right)$ correlate with one another, proving that the $\mathrm{CH}_{3}$ and $\mathrm{CH}_{2}$ functional groups are directly bonded in $\mathbf{1}$. According to HMBC analysis, three cross-peaks appeared (Table 2; Fig. S3). Thus, the $\mathrm{CH}_{2}$ functional group is bonded to both the $\mathrm{CH}_{3}$, and the $\mathrm{OCS}_{2}$ functional group and the sequence of functional groups in $\mathbf{1}$ can be derived as $\mathrm{CH}_{3}-\mathrm{CH}_{2}-\mathrm{O}-\mathrm{CS}_{2}-$. The quantitative 1D ${ }^{1} \mathrm{H}$ NMR experiment showed that the molar ratio of $\mathrm{CH}_{3}$ functional groups in $\mathbf{1}$ to $2-\mathrm{PrOH}$ is 1.42 (expected 1.50, i.e., , 3/2). As $\approx 5 \mathrm{~mol} \%$ of 1 is $\mathrm{Sb}_{2} \mathrm{~S}_{3}$, then the molar ratio of $\mathrm{CH}_{3}$ in the EX ligand to $\mathrm{Sb}^{3+}$ is close to the expected stoichiometric value of 3 .

In summary, FTIR showed that the vibrational modes of $\mathbf{1}$ correspond to only SbEX, and the main bands had shifted in comparison to KEX, indicating the formation of a complex with a more electronegative metal. XRD showed that only rhombohedral SbEX was detected in 1. Raman showed that bands attributed to only $\mathbf{1}$ were detected. Further investigation by NMR showed that there are approximately three ligands per molecule of $\mathbf{1}$ with the structure of $-\mathrm{S}_{2} \mathrm{COCH}_{2} \mathrm{CH}_{3}$, i.e., the EX ligand. According to quantitative ${ }^{1} \mathrm{H}$ NMR, 1 contains approximately $95 \mathrm{~mol} \%$ of SbEX. The slight deficiency of $\mathrm{S}$ was also observed by EDX ( $95 \pm 2 \mathrm{~mol} \%$ of theoretical value). The remaining $5 \mathrm{~mol} \%$ was identified as amorphous $\mathrm{Sb}_{2} \mathrm{~S}_{3}$ by Raman. Therefore, 1 has been identified as $95 \mathrm{~mol} \% \mathrm{Sb}\left(\mathrm{S}_{2} \mathrm{COCH}_{2} \mathrm{CH}_{3}\right)_{3}-\mathrm{SbEX}$, and $5 \mathrm{~mol} \%$ of amorphous $\mathrm{Sb}_{2} \mathrm{~S}_{3}$.

\section{Thermal analysis}

According to TG curves of 1 (Fig. 2), the thermal decomposition occurred in three mass loss steps in argon in the range of $90-800^{\circ} \mathrm{C}$, whereas in synthetic air, four mass loss steps were observed in the range of $90-590{ }^{\circ} \mathrm{C}$. The endothermic step at $85{ }^{\circ} \mathrm{C}$ in both atmospheres is the melting point of $\mathbf{1}$, because in laboratory test, a melting point of 1 of $77 \pm 1^{\circ} \mathrm{C}$ was measured on slow heating in air $\left(c f .75^{\circ} \mathrm{C}\right.$ in [32], $68-70{ }^{\circ} \mathrm{C}$ in [33]), wherein a viscous adhesive clear yellow liquid formed. The first mass loss step was endothermic in both atmospheres, as DTA peaked at $140{ }^{\circ} \mathrm{C}$, preceding the DTG maximum at $135^{\circ} \mathrm{C}$. Similarly, in both atmospheres, two consecutive exothermic effects occurred in the second mass loss step at $235^{\circ} \mathrm{C}$ and $250{ }^{\circ} \mathrm{C}$ in argon, and $235^{\circ} \mathrm{C}$ and $245^{\circ} \mathrm{C}$ in synthetic air, together with a DTG maximum 
Fig. 2 TG, DTG, and DTA curves of $\mathbf{1}$ in $\mathbf{a}$ argon, flow $60 \mathrm{~mL} \mathrm{~min}^{-1}$, heating rate $10^{\circ} \mathrm{min}^{-1}$, initial mass $11.6 \mathrm{mg}$, and $\mathbf{b}$ synthetic air, flow $60 \mathrm{~mL} \mathrm{~min}^{-1}$, heating rate $10^{\circ} \mathrm{min}^{-1}$, initial mass $13.9 \mathrm{mg}$, as measured in situ by the online coupled TG/DTA-MS system

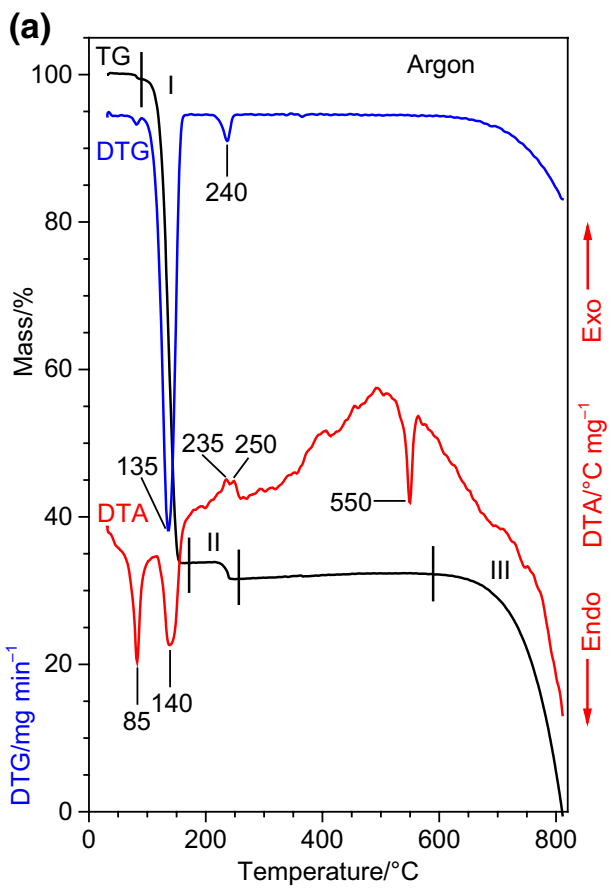

positioned at $240{ }^{\circ} \mathrm{C}$ in argon, and $235^{\circ} \mathrm{C}$ in synthetic air, respectively.

Mass was constant in argon between 250 and $590{ }^{\circ} \mathrm{C}$, although a sharp endothermic effect occurred at $550{ }^{\circ} \mathrm{C}$. A broad endothermic effect occurred throughout the third mass loss step in argon beginning at $600{ }^{\circ} \mathrm{C}$. An intense exothermic effect appeared in the third mass loss step in synthetic air, peaking at $365^{\circ} \mathrm{C}$, trailing the DTG peak at $350{ }^{\circ} \mathrm{C}$. A weaker exothermic effect occurred in the fourth mass loss step in synthetic air at $570{ }^{\circ} \mathrm{C}$ simultaneously with the DTG peak at $570{ }^{\circ} \mathrm{C}$.

The first mass loss step in both atmospheres was in the range of $90-170{ }^{\circ} \mathrm{C}$ with mass losses of $66.3 \%$ in argon, and $61.1 \%$ in synthetic air. The second mass loss step was in the range of $170^{\circ} \mathrm{C}-255^{\circ} \mathrm{C}$ in argon, and $170{ }^{\circ} \mathrm{C}-250^{\circ} \mathrm{C}$ in synthetic air, with mass loss of $2.1 \%$ in both cases. The third mass loss step started in argon at $590{ }^{\circ} \mathrm{C}$, proceeding until $810^{\circ} \mathrm{C}$, where all of the remaining mass was lost. The mass

Table 3 Decomposition steps, mass losses, temperatures of DTA and DTG peaks, evolved gases, and detected crystalline phases of $\mathbf{1}$. TG/

and synthetic air atmosphere with open $\mathrm{Al}_{2} \mathrm{O}_{3}$ crucible on a Setaram LabSys EVO instrument

DTA-MS data recorded using a heating rate of $10{ }^{\circ} \mathrm{C} \mathrm{min}^{-1}$ in argon,

\begin{tabular}{|c|c|c|c|c|c|c|c|}
\hline Atmosphere & Step & $\begin{array}{l}\text { Tem- } \\
\text { perature } \\
\text { range } /{ }^{\circ} \mathrm{C}\end{array}$ & $\begin{array}{l}\text { Mass loss at the end } \\
\text { of the decomposition } \\
\text { step } / \%\end{array}$ & DTA peak temp. $/{ }^{\circ} \mathrm{C}$ & $\begin{array}{l}\text { DTG } \\
\max \\
\text { temp. } /{ }^{\circ} \mathrm{C}\end{array}$ & $\begin{array}{l}\text { Evolved gases from } \\
\text { MS }^{\mathrm{a}}\end{array}$ & $\begin{array}{l}\text { Crystalline phases at the } \\
\text { end of the decomposition } \\
\text { step (XRD data), ICDD } \\
\text { PDF No }\end{array}$ \\
\hline \multirow[t]{4}{*}{$\mathrm{Ar}$} & 1 & $90-170$ & 66.3 & 140 endo & 135 & \multirow{2}{*}{$\begin{array}{l}\mathrm{CS}_{2}, \mathbf{E t O H}, \mathrm{CO}, \mathrm{CO}_{2} \text {, } \\
\quad \mathrm{COS} \\
\mathrm{H}_{2} \mathrm{O}, \mathrm{EtSH}, \mathrm{SO}_{2}\end{array}$} & None \\
\hline & 2 & $170-255$ & 68.4 & 235 exo, 250 exo & 240 & & $\begin{array}{l}\mathrm{Sb}_{2} \mathrm{~S}_{3} \text { (stibnite, 01-075- } \\
4012 \text { ) }\end{array}$ \\
\hline & 3 & $590-800$ & 100 & - & - & - & $\begin{array}{l}\mathrm{Sb}_{2} \mathrm{~S}_{3}, \mathrm{Sb}(05-0562) \text { at } \\
\quad 730{ }^{\circ} \mathrm{C}\end{array}$ \\
\hline & Final & $800^{\circ} \mathrm{C}$ & 100 & & & & no solid residue \\
\hline \multirow[t]{5}{*}{$\mathrm{Ar}+\mathrm{O}_{2}$} & 1 & $90-170$ & 61.1 & 140 endo & 135 & \multirow{2}{*}{$\begin{array}{l}\mathrm{CS}_{2}, \mathbf{E t O H}, \mathrm{CO}, \mathrm{CO}_{2}, \\
\quad \mathbf{C O S} \\
\mathrm{H}_{2} \mathrm{O}, \mathrm{EtSH}, \mathrm{SO}_{2}\end{array}$} & None \\
\hline & 2 & $170-250$ & 63.2 & 235 ехо, 245 exо & 235 & & $\mathrm{Sb}_{2} \mathrm{~S}_{3}$ \\
\hline & 3 & $250-495$ & 65.8 & 365 exo & 350 & $\mathrm{SO}_{2}$ & $\begin{array}{c}\mathrm{Sb}_{2} \mathrm{O}_{4} \text { (cervantite, } \\
01-074-8714 \text { ) }\end{array}$ \\
\hline & 4 & $495-590$ & 66.8 & 570 exo & 570 & $\mathrm{SO}_{2}$ & $\mathrm{Sb}_{2} \mathrm{O}_{4}\left(600{ }^{\circ} \mathrm{C}\right)$ \\
\hline & Final & $600^{\circ} \mathrm{C}$ & 66.8 & & & & $\mathrm{Sb}_{2} \mathrm{O}_{4}$ \\
\hline
\end{tabular}

${ }^{\mathrm{a}}$ Major gases in bold 
loss of $\mathbf{1}$ in argon above $590{ }^{\circ} \mathrm{C}$ is the result of incongruent evaporation of liquid $\mathrm{Sb}_{2} \mathrm{~S}_{3}$ per the $\mathrm{Sb}-\mathrm{S}$ phase diagram [5, $7,54]$, as the product collected at $730{ }^{\circ} \mathrm{C}$ consisted of crystalline $\mathrm{Sb}_{2} \mathrm{~S}_{3}$ and metallic $\mathrm{Sb}$ according to XRD (Table 3).

In synthetic air, the third mass loss step was in the range of $250-495{ }^{\circ} \mathrm{C}$ with mass loss of $2.6 \%$. The fourth mass loss step in synthetic air was in the range of $495-590{ }^{\circ} \mathrm{C}$ with mass loss of $1.0 \%$. Final mass loss was $100 \%$ in argon at $800{ }^{\circ} \mathrm{C}$, and $66.8 \%$ in synthetic air at $600{ }^{\circ} \mathrm{C}$. The theoretical mass loss in argon at $600{ }^{\circ} \mathrm{C}$ is $65.0 \%$ (experimental $68.3 \%$ ), assuming pure $\mathrm{Sb}_{2} \mathrm{~S}_{3}$ phase. The theoretical mass loss in air is $68.3 \%$, as the final product in synthetic air was $\mathrm{Sb}_{2} \mathrm{O}_{4}$. The final mass loss of $\mathbf{1}$ in synthetic air was lower than calculated due to presence of $\mathrm{Sb}_{2} \mathrm{~S}_{3}$ in $\mathbf{1}$.

\section{Evolved gas analysis in argon and synthetic air atmosphere by online EGA-MS}

The evolution curves of gases as ion currents of characteristic mass fragments of the identified gaseous species vs temperature evolved from $\mathbf{1}$ in argon, and in synthetic air in comparison, as recorded by online EGA-MS, are shown in Fig. 3. Peak centers and assignments of all measured EGAMS channels are listed in Table S4.

According to EGA-MS in argon, the evolution of gases started at $50{ }^{\circ} \mathrm{C}$ with the evolution of adsorbed moisture as water $\left(\mathrm{H}_{2} \mathrm{O}\right)$ with characteristic ion fragment of $\mathrm{m} / \mathrm{z} 18$, peaking at $82{ }^{\circ} \mathrm{C}$. Evolution of water below $100{ }^{\circ} \mathrm{C}$ was not detected in synthetic air likely because the sample was purged for an extended period of time $v$ s the sample in argon before commencing the EGA-MS run. (a)

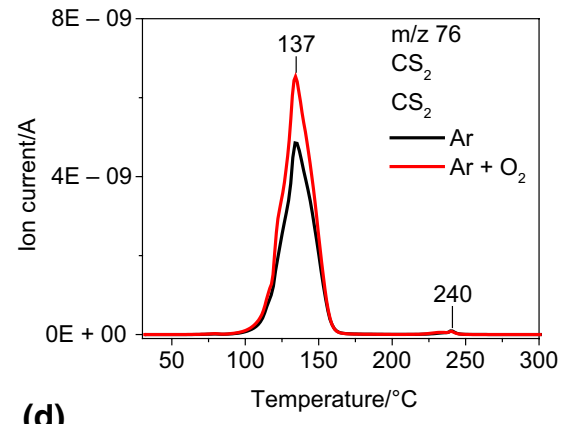

(d)
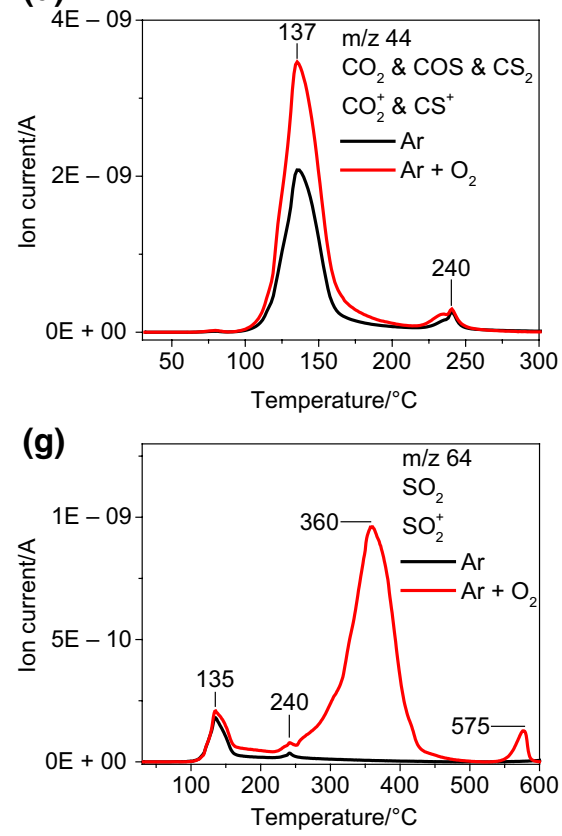

(b)

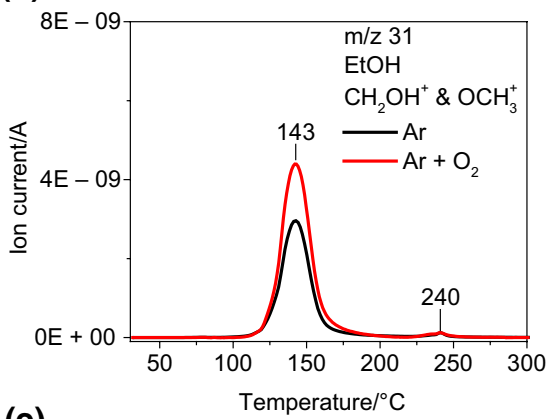

(e)

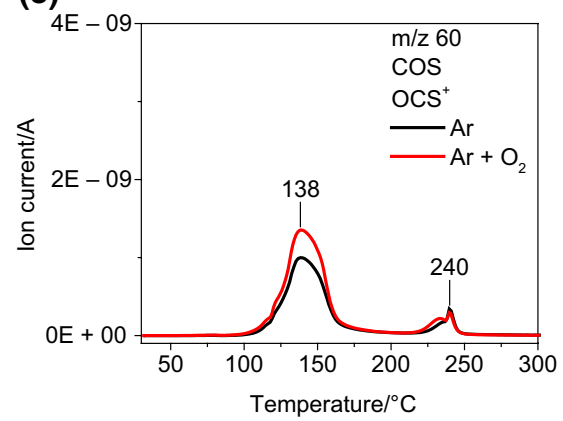

(h)

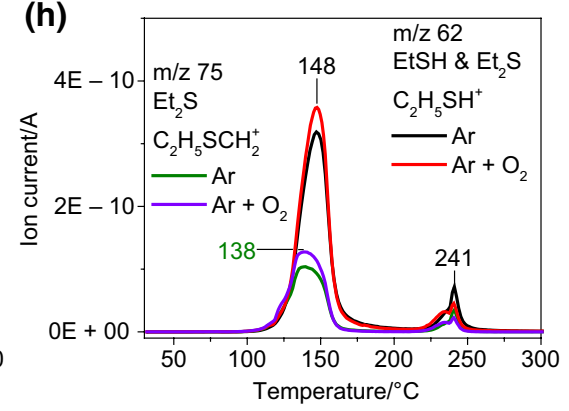

(c)

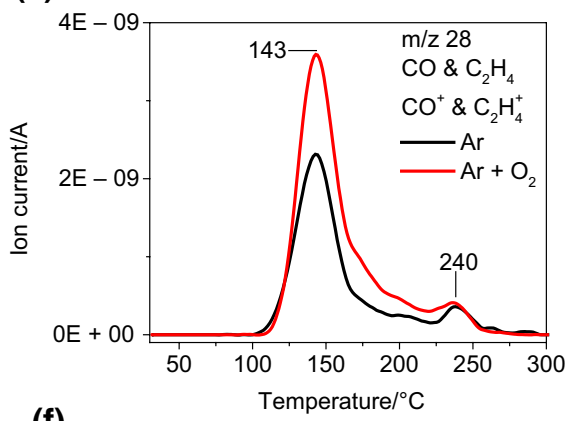

(f)

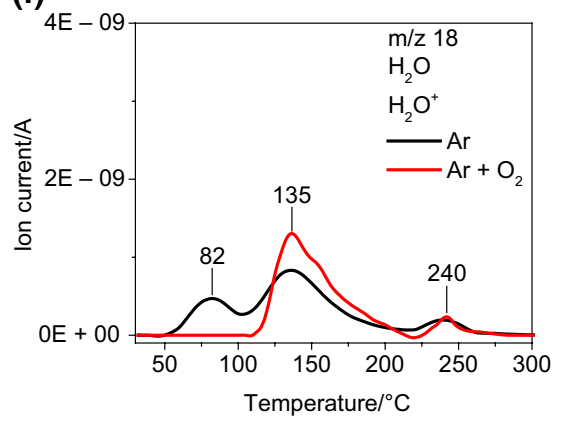

(i)

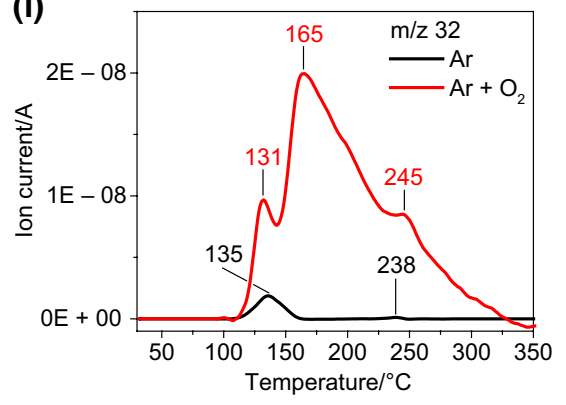

Fig. 3 Gas evolution profiles of $\mathrm{CS}_{2}$ a, EtOH b, $\mathrm{CO}$ and $\mathrm{C}_{2} \mathrm{H}_{2} \mathbf{c}$, $\mathrm{CO}_{2}, \mathrm{CS}_{2}$, and $\mathrm{COS} \mathbf{d}, \mathrm{COS} \mathbf{e}, \mathrm{H}_{2} \mathrm{O}$ f, $\mathrm{SO}_{2} \mathbf{g}, \mathrm{EtSH}$ and $\mathrm{Et}_{2} \mathrm{~S} \mathbf{h}$, and unknown $\mathrm{m} / \mathrm{z} 32 \mathrm{i}$, represented by their characteristic mass spectroscopic ion fragments, from $\mathbf{1}$ in argon (in black or green), flow
$60 \mathrm{~mL} \mathrm{~min}^{-1}$, heating rate $10^{\circ} \mathrm{min}^{-1}$, initial mass $11.6 \mathrm{mg}$, and in synthetic air (in red or violet), flow $60 \mathrm{~mL} \mathrm{~min}^{-1}$, heating rate $10^{\circ} \mathrm{min}^{-1}$, initial mass $13.9 \mathrm{mg}$, as measured by in situ online coupled TG/DTA-EGA-MS system. (Color figure online) 
The first decomposition step $\left(90-170{ }^{\circ} \mathrm{C}\right)$ began similarly in argon and synthetic air with the evolution of several gases: carbon disulfide $\left(\mathrm{CS}_{2}, m / z 76\right.$, Fig. 3a), ethanol (EtOH, $\mathrm{m} / \mathrm{z}$ 31, Fig. 3b), carbon monoxide $(\mathrm{CO}, \mathrm{m} / \mathrm{z} 28$, Fig. 3c; possibly partially attributable to $\mathrm{C}_{2} \mathrm{H}_{4}$ ), carbon dioxide $\left(\mathrm{CO}_{2}, \mathrm{~m} / z\right.$ 44, Fig. 3d; partially attributable to $\mathrm{CS}^{+}$from $\mathrm{CS}_{2}$ and COS), carbonyl sulfide (COS, $\mathrm{m} / \mathrm{z} 60$, Fig. 3e), water ( $m / z$ 18, Fig. 3f), and sulfur dioxide $\left(\mathrm{SO}_{2}\right.$, $\mathrm{m} / z$ 64, Fig. 3g), Substantial evolution of gaseous fragments corresponding to the methyl group $\left(\mathrm{CH}_{3}, \mathrm{~m} / z, 15\right.$, Fig. S4a), and the ethyl or formyl group $\left(\mathrm{C}_{2} \mathrm{H}_{5}\right.$ or $\mathrm{CHO}$, $m / z$ 29, Fig. S4b) was also detected. Evolution of some minor gases was also detected, e.g., ethanethiol (EtSH, $m / z$ 62, Fig. 3h), diethyl sulfide ( $\mathrm{Et}_{2} \mathrm{~S}, m / z, 75$, Fig. 3h), diethyl ether $\left(\mathrm{Et}_{2} \mathrm{O}, \mathrm{m} / z, 74\right.$, Fig. $\left.\mathrm{S} 4 \mathrm{c}\right)$ and dixanthogen $\left(\left(\mathrm{EX}_{2}\right), m / z\right.$ 89, Fig. S4d).

In argon, the evolution curve of the tentatively unassigned $\mathrm{m} / \mathrm{z} 32$ corresponded to $\mathrm{CS}_{2}, \mathrm{COS}$, and $\mathrm{SO}_{2}$, with a maximum at $135^{\circ} \mathrm{C}$. Thus, in argon, $m / z 32$ is attributed to the $\mathrm{S}^{+}$fragment of $\mathrm{CS}_{2}, \mathrm{COS}$, and $\mathrm{SO}_{2}$, and possibly to molecular $\mathrm{MeOH}$. The evolution curve of $\mathrm{m} / \mathrm{z} 32$ in synthetic air is a conundrum, because after $131{ }^{\circ} \mathrm{C}$ the curve is unlike any of the monitored $\mathrm{m} / \mathrm{z}$ channels, its intensity looming over other gases by an order of magnitude without mass loss nor any DTA effects. This strange phenomenon was observed in experiments run in synthetic air with $\mathrm{Al}_{2} \mathrm{O}_{3}$ and $\mathrm{Pt}$ crucible (not shown), where the shape and intensity of the evolution curve were similarly anomalous. In synthetic air, $m / z, 32$ could correspond to $\mathrm{S}^{+}\left(\mathrm{COS}, \mathrm{CS}_{2}\right.$, $\mathrm{H}_{2} \mathrm{~S}, \mathrm{~S}_{8}$ ), or $\mathrm{MeOH}$, but comparison to other $m / z$ curves disproved this possibility. Therefore, $\mathrm{m} / \mathrm{z} 32$ in synthetic air remained unresolved in this study.

The second decomposition step $\left(170-255^{\circ} \mathrm{C}\right.$ in argon, $170-250{ }^{\circ} \mathrm{C}$ in synthetic air) proceeded with the evolution of $\mathrm{CS}_{2}, \mathrm{EtOH}, \mathrm{CO}, \mathrm{CO}_{2}, \mathrm{COS}, \mathrm{H}_{2} \mathrm{O}, \mathrm{SO}_{2}, \mathrm{EtSH}, \mathrm{Et}_{2} \mathrm{~S}$, $\mathrm{Et}_{2} \mathrm{O}$, and $(\mathrm{EX})_{2}$ in a proportionally smaller quantity, reflecting the $\approx 30$ times smaller mass loss in the second decomposition step compared to the first $(2.1 \%$ vs. $66.3 \%$ in argon; $2.1 \%$ vs. $61.1 \%$ in synthetic air). In the second decomposition step in argon, and synthetic air the evolution curves of gases were asymmetric, tailing toward lower temperatures, peaking at $240{ }^{\circ} \mathrm{C}$. The asymmetric evolution curve in EGA-MS supports the TG/DTA results in that two consecutive exothermic processes occur in the second decomposition step, peaking at $235^{\circ} \mathrm{C}$ and $250{ }^{\circ} \mathrm{C}$ in argon, and at $235^{\circ} \mathrm{C}$ and $245^{\circ} \mathrm{C}$ in synthetic air (Fig. 2). The evolution of most gaseous species ceased by the end of the second decomposition step at $\approx 270{ }^{\circ} \mathrm{C}$, indicating complete decomposition of organic material. In argon, no evolution of gases was detected beyond $270{ }^{\circ} \mathrm{C}$, whereas in synthetic air, only $\mathrm{SO}_{2}$ and $\mathrm{m} / \mathrm{z} 32$ continued to evolve.

In the third decomposition step in synthetic air $\left(250-495{ }^{\circ} \mathrm{C}\right), \mathrm{SO}_{2}$ evolved in a significantly larger amount than in the first and second step, peaking at $360{ }^{\circ} \mathrm{C}$. In the fourth decomposition step in synthetic air $\left(495-590{ }^{\circ} \mathrm{C}\right)$, $\mathrm{SO}_{2}$ evolved from 530 to $590{ }^{\circ} \mathrm{C}$, peaking at $575{ }^{\circ} \mathrm{C}$. The evolution curve of $\mathrm{SO}_{2}$ in synthetic air closely resembles the DTA curve (Fig. 2b), and follows the DTG peak positions in the temperature range of $200-600{ }^{\circ} \mathrm{C}$, indicating that the exothermic DTA effects in that temperature range in synthetic air are directly related to the evolution of $\mathrm{SO}_{2}$.

\section{Discussion of thermal analysis results}

To establish the basis for describing the decomposition mechanism of $\mathbf{1}$, laboratory tests were made to investigate the phase composition of the solid intermediate decomposition products of $\mathbf{1}$ at various temperatures in inert and air atmosphere. These intermediate decomposition products of 1 were characterized by FTIR, XRD, and Raman to determine the phase composition at various stages of the decomposition process.

The slight difference in FTIR spectra of some band positions of $\mathbf{1}$ in respect to measurements by $\mathrm{KBr}$ method is attributed to differences in instrument setup and measurement mode (Fig. 1 vs. Fig. 4). Tentative FTIR assignments in the following discussion are based on the literature [36, 38, 41-43, 48-50, 55-57]. According to FTIR, the vibrational modes of the intermediate decomposition product prepared at $115^{\circ} \mathrm{C}$ in $\mathrm{N}_{2}$ are nearly identical to those of $\mathbf{1}$ (Fig. 4a).

By $160{ }^{\circ} \mathrm{C}$, the FTIR spectrum has changed significantly, as bands attributed to $\mathrm{CH}_{3}$ and $\mathrm{CH}_{2}$ stretching (2800-3000 $\left.\mathrm{cm}^{-1}\right)$, scissoring $\left(1386 \mathrm{~cm}^{-1}, 1443 \mathrm{~cm}^{-1}\right.$, $\left.1468 \mathrm{~cm}^{-1}\right)$, twisting $\left(1075 \mathrm{~cm}^{-1}\right)$, and rocking $\left(813 \mathrm{~cm}^{-1}\right)$ modes have disappeared, indicating that the ethyl group $\left(\mathrm{CH}_{3} \mathrm{CH}_{2}-\right)$ has been cleaved, and has exited into the gas phase. Furthermore, the $\mathrm{O}-\mathrm{C}-\mathrm{C}$ scissoring $\left(407 \mathrm{~cm}^{-1}\right.$, $436 \mathrm{~cm}^{-1}$ ) of the ethyl group has disappeared, in correlation with EGA-MS results, where evolution of EtOH peaked at $143{ }^{\circ} \mathrm{C}$, and ended by $160-165^{\circ} \mathrm{C}$ (Fig. 3b). Adsorbed water has evolved by $160{ }^{\circ} \mathrm{C}$ in $\mathrm{N}_{2}$, because the broad band (O-H stretching, $3000-3700 \mathrm{~cm}^{-1}$ ) is not present in the spectrum of the solid intermediate (Fig. 4a). Moreover, by $160{ }^{\circ} \mathrm{C}$ in $\mathrm{N}_{2}$, bands have shifted from $995 \mathrm{~cm}^{-1}$ to $967 \mathrm{~cm}^{-1}(\mathrm{C}=\mathrm{S}$ symmetric stretching; bond elongation), from $1230 \mathrm{~cm}^{-1}$ to $1254 \mathrm{~cm}^{-1}$ (C-O-C asymmetric stretching; bond shortening), and from $1682 \mathrm{~cm}^{-1}$ to $1643 \mathrm{~cm}^{-1}$ (conjugated $\mathrm{C}=\mathrm{O}$ stretching; bond elongation) (Fig. 4a). The shift in band positions and new bands at $870 \mathrm{~cm}^{-1}$ (O-C-S stretching), and $2021 \mathrm{~cm}^{-1}(\mathrm{~S}-\mathrm{C}=\mathrm{O}$ stretching) likely indicates the formation of a monothiocarbonate ligand $\left(\mathrm{CSO}_{2}{ }^{2-}\right)$.

The FTIR spectrum of the solid intermediate prepared at $115^{\circ} \mathrm{C}$ in air is similar to the spectra of $\mathbf{1}$ and the solid intermediate prepared at $115{ }^{\circ} \mathrm{C}$ in $\mathrm{N}_{2}$, although some features differ: a $\mathrm{C}=\mathrm{O}$ stretching band at $1643 \mathrm{~cm}^{-1}$ in air $v s 1742 \mathrm{~cm}^{-1}$ in $\mathrm{N}_{2}$, and a more intense band between 
Fig. 4 FTIR spectra of 1 and its intermediate decomposition products prepared in laboratory tests in $\mathrm{N}_{2}$ a, and in air b in the first decomposition step at $115^{\circ} \mathrm{C}$ and $160^{\circ} \mathrm{C}$, as measured with diamond anvil in reflectance mode at resolution of $4 \mathrm{~cm}^{-1}, 24$ scans
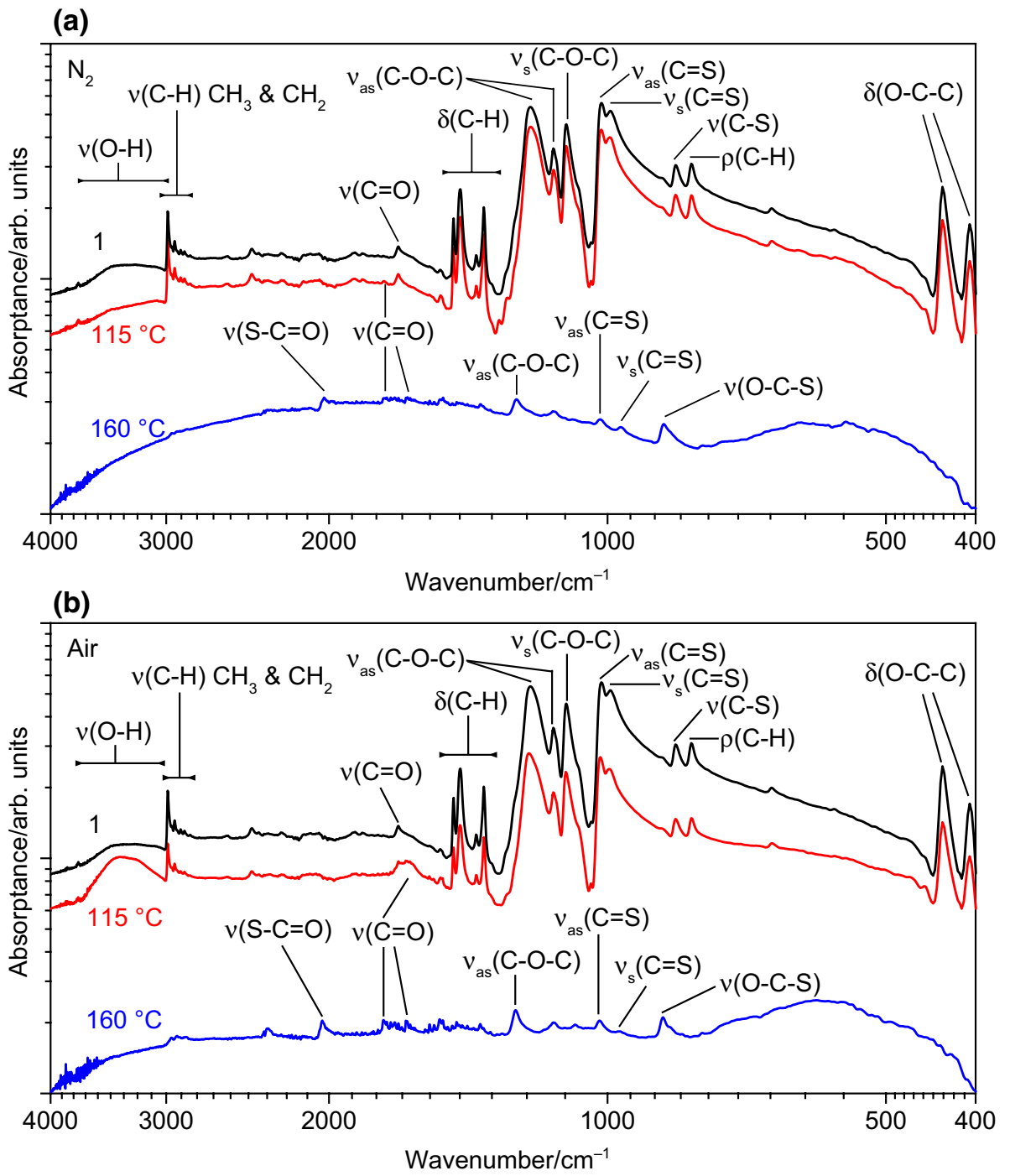

$3000-3700 \mathrm{~cm}^{-1}$ than in $\mathbf{1}(\mathrm{O}-\mathrm{H}$ stretching), showing that free water has formed during the decomposition of $\mathbf{1}$ due to air oxidation of the ethyl group. The FTIR spectrum of the solid intermediate prepared at $160{ }^{\circ} \mathrm{C}$ in air is similar to the spectrum of the residue prepared at $160{ }^{\circ} \mathrm{C}$ in $\mathrm{N}_{2}$, except a weak residual of the ethyl group at $2800-3000 \mathrm{~cm}^{-1}\left(\mathrm{CH}_{3}\right.$, $\mathrm{CH}_{2}$ stretching) possibly due to insufficient time for decomposition of $\mathbf{1}$ in laboratory test. In summary, the intermediate decomposition products prepared at $160{ }^{\circ} \mathrm{C}$ in $\mathrm{N}_{2}$, and in air appear to contain one or more ligands composed of $\mathrm{C}=\mathrm{O}$, $\mathrm{C}-\mathrm{S}, \mathrm{O}=\mathrm{C}-\mathrm{S}, \mathrm{O}-\mathrm{C}-\mathrm{S}$, and possibly $\mathrm{C}-\mathrm{O}-\mathrm{C}$ fragments, with traces of ethyl group.

The main gases $\mathrm{CS}_{2}$, EtOH, $\mathrm{CO}, \mathrm{CO}_{2}, \mathrm{COS}$, and $\mathrm{H}_{2} \mathrm{O}$ co-evolve in the first decomposition step, thus, the decomposition of SbEX cannot proceed merely by direct cleavage of the EX ligand, and must proceed through one or more parallel reactions. As SbEX is liquid before and during the decomposition, liquid-phase radical and ionic reactions that are common for xanthate reactions should occur [35, 37].
$\mathrm{COS}, \mathrm{CS}_{2}$ and EtOH likely form via competing reactions, where one $\mathrm{Sb}-\mathrm{S}$ coordination bond is broken, followed by intramolecular rearrangement of bonds between the alkoxy and dithiocarbonyl group (Scheme 1, reaction 1 and reaction 2 ). With rotation of the dithiocarbonyl group, followed by cleavage of $\mathrm{COS}$ that evolves as a gas, $\mathrm{Sb}\left(\mathrm{R}_{1}\right)\left(\mathrm{R}_{2}\right) \mathrm{SCH}_{2} \mathrm{CH}_{3}$ is produced (Scheme 1, reaction 1a). Without rotation of the dithiocarbonyl group, $\mathrm{CS}_{2}$ is cleaved, evolving as a gas, and $\mathrm{Sb}\left(\mathrm{R}_{1}\right)\left(\mathrm{R}_{2}\right) \mathrm{OCH}_{2} \mathrm{CH}_{3}$ (Scheme 1, reaction 2a) is produced. Reaction 2 and reaction $2 \mathrm{a}$ in Scheme 1 is most likely the main reaction, as this sequence is the most straightforward and credible source of $\mathrm{CS}_{2}$-the main evolved gas. Reaction $2 \mathrm{a}$ is likely thermodynamically preferred over reaction $1 \mathrm{a}$ in Scheme 1, as rotation of the dithiocarbonyl group, and redistribution of twice as many bonds in reaction 1a vs reaction 2a requires overcoming a higher activation energy barrier.

In Scheme 1, Reaction 1a accounts for COS, and reaction $2 \mathrm{a}$ for $\mathrm{CS}_{2}$. Thus, further reactions are needed to explain the evolution of $\mathrm{CO}_{2}, \mathrm{CO}, \mathrm{EtOH}$, and $\mathrm{H}_{2} \mathrm{O}$. Also, EtSH as a 


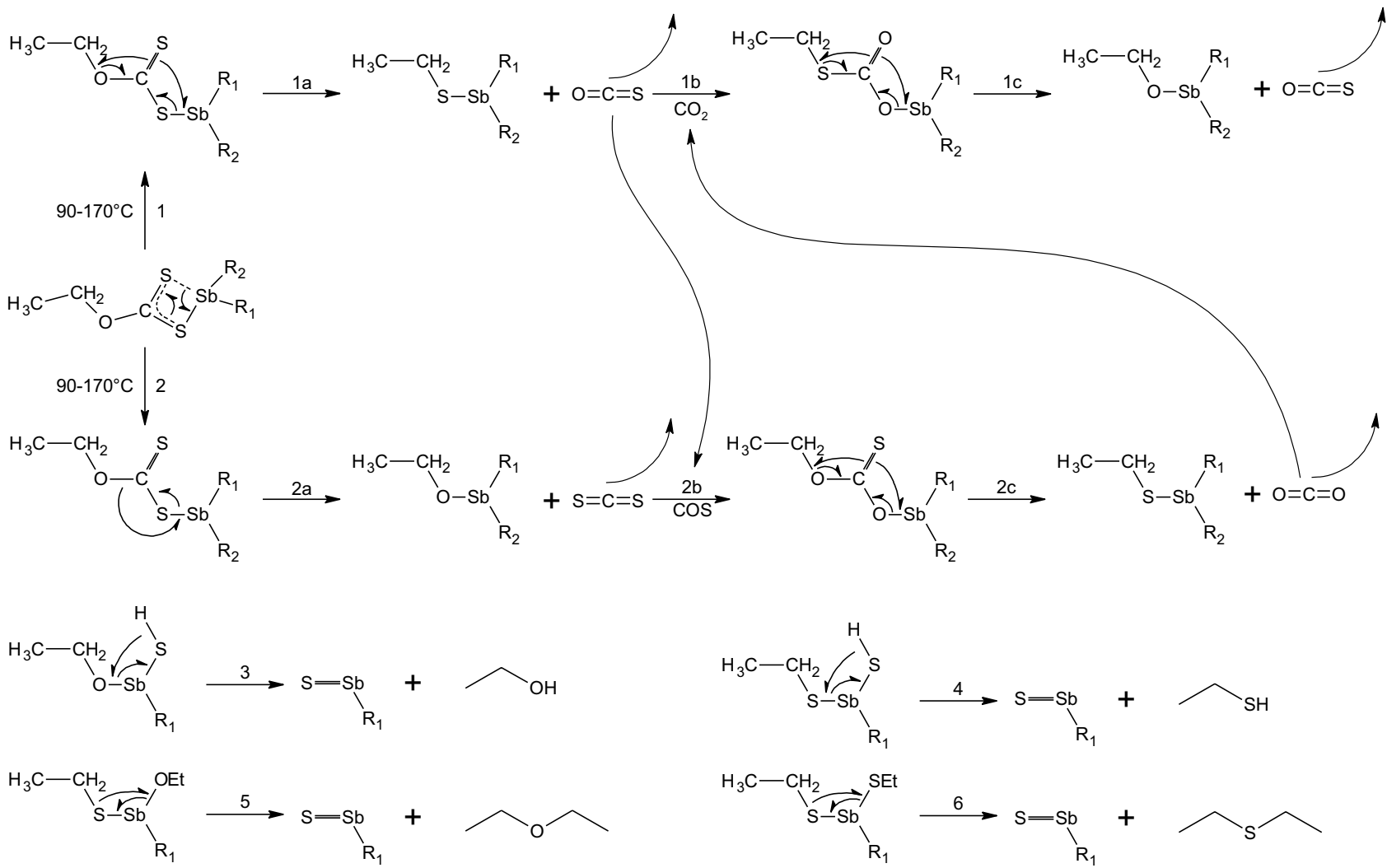

Scheme 1 Proposed decomposition reactions of SbEX occurring in the first decomposition step. $\mathrm{R}_{1}, \mathrm{R}_{2}=\mathrm{EX} / \mathrm{EtO} / \mathrm{EtS}_{/} \mathrm{CSO} / \mathrm{CSO} \mathrm{Et}_{2} / \mathrm{SH}$

minor gas probably forms in two reaction steps because of steric inhibition of interaction between $\mathrm{S}$ and $\mathrm{CH}_{3} \mathrm{CH}_{2}$ - in the EX ligand, as evinced by NMR and EGA-MS results. Mirroring reaction $1 \mathrm{a}, \mathrm{CO}_{2}$ and $\mathrm{EtSH}$ could be produced by reaction $2 \mathrm{c}$ in Scheme 1 , whereby COS is injected into $\mathrm{Sb}\left(\mathrm{R}_{1}\right)\left(\mathrm{R}_{2}\right) \mathrm{OEt}(\mathrm{R}=\mathrm{EX} / \mathrm{SH} / \mathrm{EtO} / \mathrm{EtS})$, followed by rearrangement of the COS moiety to yield $\mathrm{Sb}\left(\mathrm{R}_{1}\right)\left(\mathrm{R}_{2}\right) \mathrm{SEt}$ and $\mathrm{CO}_{2}$. Reactions like $1 \mathrm{~b}$ and $2 \mathrm{~b}$ in Scheme 1, where the metal hydroxide, thiol, alkoxide, or mercaptane reacts as a Lewis base with $\mathrm{CS}_{2}, \mathrm{COS}$, or $\mathrm{CO}_{2}$ anhydride as Lewis acid, are known to form carbonates, thiocarbonates, and their alkyl-substituted derivatives [58].
Fig. 5 Raman spectra of $\mathbf{1}$ and its intermediate decomposition products in laboratory tests in $\mathbf{a}$ $\mathrm{N}_{2}$, flow $60 \mathrm{~mL} \mathrm{~min}^{-1}$, heating rate $10^{\circ} \mathrm{min}^{-1}$ after pre-purging to $1 \cdot 10^{-2}$ mbar, heating time $10 \mathrm{~min}$, and in $\mathbf{b}$ air, where $\mathbf{1}$ was inserted into a preheated furnace and heated at the specified temperature for $10 \mathrm{~min}$ before withdrawal and cooling (a)

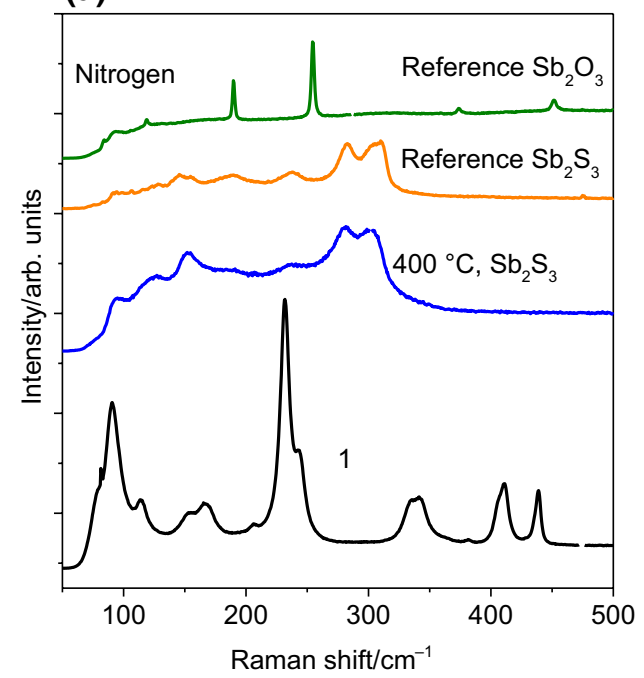

(b)

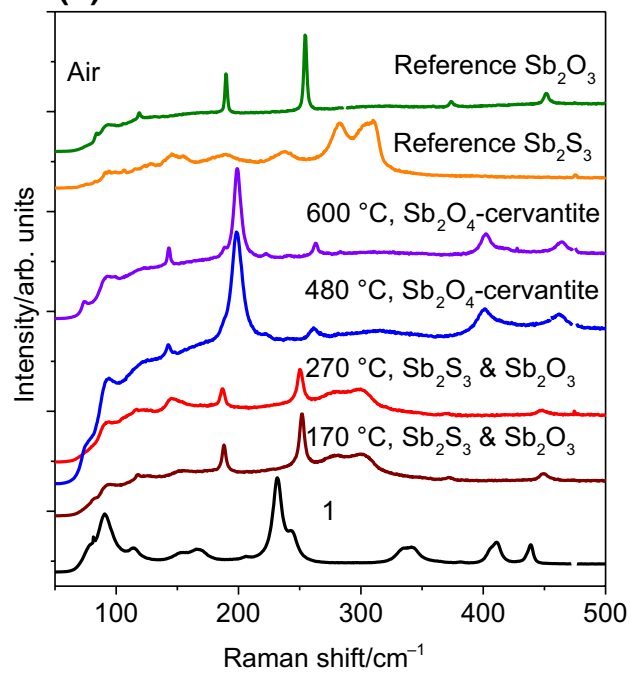


Considering the sizeable and rapid mass loss in the first decomposition step, $\mathrm{Sb}(\mathrm{EX})_{2} \mathrm{OEt}$ could degrade further by decomposition of the remaining EX ligands, followed by evolution of EtOH, e.g., reaction 3 in Scheme 1, while retaining enough $\mathrm{Sb}-\mathrm{S}$ bonds to form $\mathrm{Sb}_{2} \mathrm{~S}_{3}$, as confirmed by Raman (Fig. 5b), because no intermediate decomposition products of $\mathbf{1}$ in inert atmosphere with $\mathrm{Sb}-\mathrm{O}$ bonding were detected by neither Raman (Fig. 5a) nor XRD (Fig. 6a). By analogy to reaction 3, the remaining EX ligands of $\mathrm{Sb}(\mathrm{EX})_{2} \mathrm{SEt}$ could decompose, followed by evolution of EtSH (e.g., reaction 4 in Scheme 1).

Judging by EGA-MS evolution intensity (Fig. 3), the evolution of EtSH is an order of magnitude smaller compared to EtOH, meaning the EtS ligand likely undergoes further reactions, acting as a supply of $\mathrm{S}$ for $\mathrm{Sb}_{2} \mathrm{~S}_{3}$, i.e., reaction 5 and reaction 6 in Scheme 1, whereas EtOH evolves directly, i.e., reaction 3 in Scheme 1. Reactions 3-6 in Scheme 1 should proceed, as the interaction between ligands is not sterically inhibited, and because the ligands are small, single-bonded throughout, and therefore able to rotate around the axis of the single coordination bond with $\mathrm{Sb}$. Another possible explanation for the sparse evolution of EtSH could be that reaction $2 b$ is the rate determining step: first, because $\mathrm{Sb}\left(\mathrm{R}_{1}\right)\left(\mathrm{R}_{2}\right) \mathrm{OEt}$ is probably consumed mainly in reaction 3 in Scheme 1 to produce $\mathrm{EtOH}$; second, because the insertion of $\mathrm{COS}$ into $\mathrm{Sb}\left(\mathrm{R}_{1}\right)\left(\mathrm{R}_{2}\right) \mathrm{OEt}$ is a gas-liquid reaction limited by the concentration of COS dissolved or dispersed in the liquid mixture.

The combined intensity of evolving $\mathrm{CO}, \mathrm{COS}$ and $\mathrm{CO}_{2}$ in EGA-MS is similar to the intensity of evolving $\mathrm{CS}_{2}$, which could indicate that reaction $2 \mathrm{~b}$ in Scheme 1 is supplied with COS by reaction 1 a or reaction $1 \mathrm{c}$, and with $\mathrm{Sb}\left(\mathrm{R}_{1}\right)\left(\mathrm{R}_{2}\right) \mathrm{OEt}$ by reaction $2 \mathrm{a}$ or reaction $1 \mathrm{c}$ in Scheme 1 . Reaction $1 \mathrm{c}$ in Scheme 1 is unlikely to contribute significantly to the thermal decomposition of $\mathbf{1}$, because it requires gaseous $\mathrm{CO}_{2}$ as reactant, which forms in reaction $2 \mathrm{c}$, in turn dependent on COS produced in reaction 1a. Consequently, reaction 1c in Scheme 1 has 6 prerequisite reaction steps before it can occur.

$\mathrm{Et}_{2} \mathrm{O}$ and $\mathrm{Et}_{2} \mathrm{~S}$ are minor byproducts, probably forming via proton transfer between intermediate neighbor ligands and subsequent cleavage from $\mathrm{Sb}$, e.g., reaction 4 and reaction 6 in Scheme $1 . \mathrm{SO}_{2}$ as a minor gas likely forms in argon by hydrolysis of $\mathrm{COS}$ or $\mathrm{CS}_{2}$ to $\mathrm{H}_{2} \mathrm{~S}$ and $\mathrm{CO}_{2}$ or $\mathrm{CO}$, ending with $\mathrm{H}_{2} \mathrm{~S}$ oxidizing to $\mathrm{SO}_{2}$ and $\mathrm{H}_{2} \mathrm{O}$ [59]. As the quantity of protons is limited in $\mathbf{1}$ to the ethyl group in the EX ligand above $90{ }^{\circ} \mathrm{C}$, the formation of EtOH, EtSH, and $\mathrm{H}_{2} \mathrm{O}$ in argon (and air) requires the formation of an equivalent quantity of ethylene $\left(\mathrm{C}_{2} \mathrm{H}_{4}\right)$ via proton transfer to supply the protons. Therefore, the EGA-MS of $\mathrm{m} / z 28$ attributed to $\mathrm{CO}$ could be in part attributed to the evolution of $\mathrm{C}_{2} \mathrm{H}_{4}$ in addition to $\mathrm{CO}$, albeit without definitive proof, as characteristic $m / z$ of $\mathrm{C}_{2} \mathrm{H}_{4}$ overlap with EtOH and other evolved gases. $\mathrm{C}_{2} \mathrm{H}_{4}$ could react in air with $\mathrm{O}_{2}$ to form oxirane $\left(\mathrm{C}_{2} \mathrm{H}_{4}(\mathrm{O})\right)$ or acetaldehyde [4], although neither can be confirmed with EGA-MS due to overlap with $\mathrm{m} / \mathrm{z}$ of main gases. Water evolves as a product of various decomposition and condensation reactions of intermediate products in the thermal decomposition of SbEX with the atmosphere having no significant effect on its evolution. Finally, $\mathrm{CO}$ could evolve from hydrolysis of $\mathrm{CS}_{2}$ or $\mathrm{COS}$ [59], or via incomplete oxidation of EtOH.

The results of this study show that the Chugaev elimination, which is often used to describe xanthate
Fig. 6 XRD patterns of 1 and its intermediate decomposition products in laboratory tests in a $\mathrm{N}_{2}$, flow $60 \mathrm{~mL} \mathrm{~min}{ }^{-1}$, heating rate $10^{\circ} \mathrm{min}^{-1}$ after pre-purging to $1 \cdot 10^{-2}$ mbar, heating time $10 \mathrm{~min}$, and in $\mathbf{b}$ air, where $\mathbf{1}$ was inserted into a preheated furnace and heated at the specified temperature for $10 \mathrm{~min}$ before withdrawal and cooling (a)

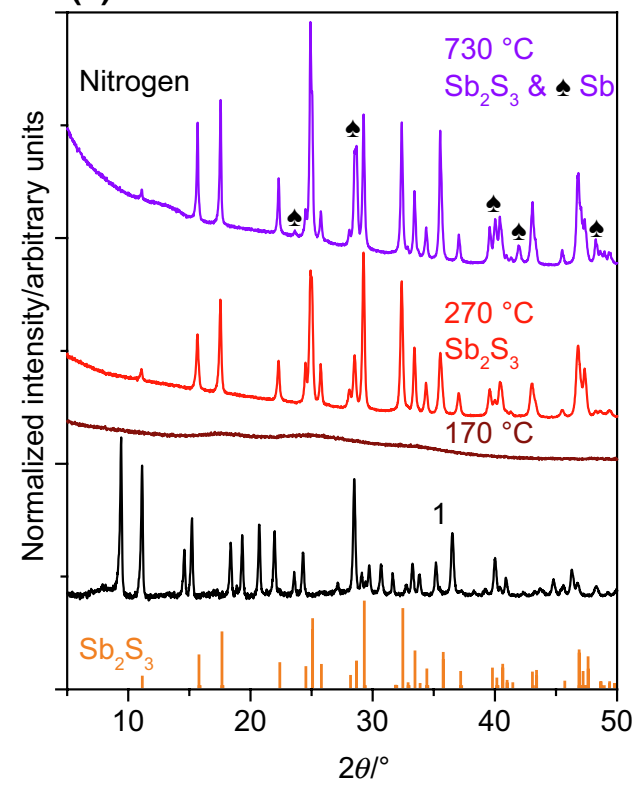

(b)

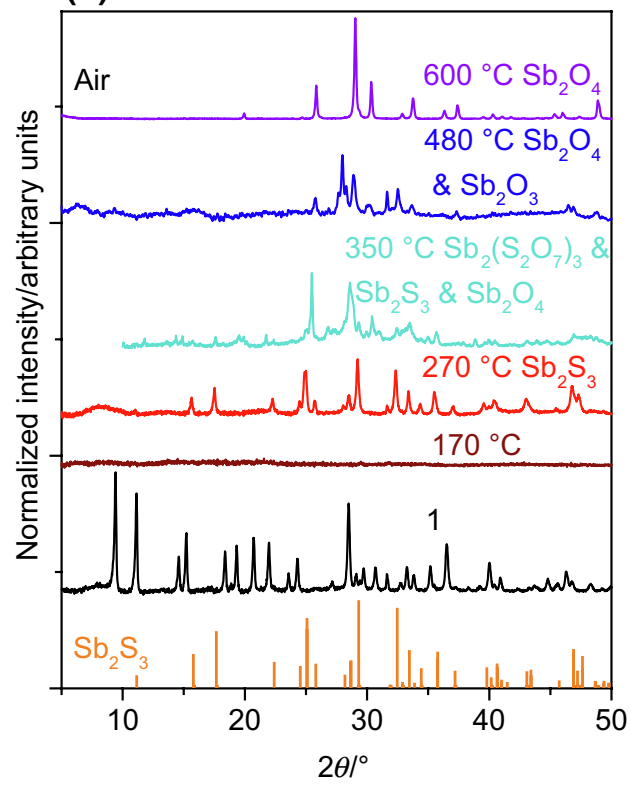


decomposition [35, 37], does not apply for $\mathbf{1}$ at all, because in it only $\mathrm{COS}$ and $\mathrm{C}_{2} \mathrm{H}_{4}$ are formed - neither the dominant gas in the first decomposition step of $\mathbf{1}$ (Fig. 3). Clearly, as the Chugaev elimination cannot explain the co-evolution of $\mathrm{CS}_{2}, \mathrm{CO}, \mathrm{CO}_{2}, \mathrm{H}_{2} \mathrm{O}, \mathrm{EtOH}, \mathrm{EtSH}, \mathrm{Et}_{2} \mathrm{~S}$, and $\mathrm{Et}_{2} \mathrm{O}$ in inert and oxidizing atmospheres, the reaction is not valid.

At the end of the first decomposition step at $170{ }^{\circ} \mathrm{C}$ in argon, and air, about 3 mass\% of the initial mass of organic species is retained in amorphous $\mathrm{Sb}_{2} \mathrm{~S}_{3}$ (Table 3). The solid intermediate prepared at $170{ }^{\circ} \mathrm{C}$ in both $\mathrm{N}_{2}$ and air was amorphous according to XRD, as seen in Fig. 6. However, according to Raman (Fig. 5b), a mixture of $\mathrm{Sb}_{2} \mathrm{~S}_{3}$ and $\mathrm{Sb}_{2} \mathrm{O}_{3}$ (senarmontite) had formed in air at $170{ }^{\circ} \mathrm{C}$ by direct oxidation of $\mathrm{Sb}_{2} \mathrm{~S}_{3}$. The asymmetric shape of the EGA-MS (Fig. 3) curves in addition to the two successive exothermic effects witnessed in DTA (Fig. 2) signifies that either more stable inorganic or organic ligands, e.g., $\mathrm{CSO}_{2}^{2-}, \mathrm{EtOCOS}^{-}, \mathrm{EtS}^{-}$, $\mathrm{EtO}^{-}$, or a separate dispersed phase has formed inside the amorphous $\mathrm{Sb}_{2} \mathrm{~S}_{3}$ phase, as seen from the FTIR spectra of solid intermediates prepared at $160^{\circ} \mathrm{C}$ (Fig. 4). Presumably, the residual organic species are expelled as the gases seen in EGA-MS (Fig. 3), followed by crystallization of purified $\mathrm{Sb}_{2} \mathrm{~S}_{3}$ (Fig. 6), as its nucleation is no longer inhibited. Elucidating the precise composition of this residual impurity in $\mathrm{Sb}_{2} \mathrm{~S}_{3}$, which persists in the solid phase over $100{ }^{\circ} \mathrm{C}$ above the first decomposition, warrants further investigation.

The second decomposition step occurred in the range of $170-255^{\circ} \mathrm{C}$ in $\mathrm{Ar}$ and $170-250{ }^{\circ} \mathrm{C}$ in synthetic air, with a mass loss of $2.1 \%$ in both cases, evolution of minor amount of $\mathrm{CS}_{2}$, EtOH, $\mathrm{CO}, \mathrm{CO}_{2}, \mathrm{COS}, \mathrm{H}_{2} \mathrm{O}, \mathrm{SO}_{2}, \mathrm{EtSH}$, $\mathrm{Et}_{2} \mathrm{~S}, \mathrm{Et}_{2} \mathrm{O}$, and (EX) $)_{2}$ (Fig. 3), and orthorhombic $\mathrm{Sb}_{2} \mathrm{~S}_{3}$ was the final solid product in inert atmosphere, and a mixture of $\mathrm{Sb}_{2} \mathrm{~S}_{3}$ and cubic $\mathrm{Sb}_{2} \mathrm{O}_{3}$ in air, as determined by Raman (Fig. 5b). Based on the FTIR analysis of the solid intermediate products (Fig. 4), antimony monothiocarbonate $\left(\mathrm{Sb}_{2}\left(\mathrm{CSO}_{2}\right)_{3}\right)$, a trace of antimony ethyl monothiocarbonate $\left(\mathrm{Sb}\left(\mathrm{SOCOCH}_{2} \mathrm{CH}_{3}\right)_{3}\right)$, and possibly other (thio)carbonyl ligands persist until $240{ }^{\circ} \mathrm{C}$. According to EGA-MS, trace quantities of presumed Sb-SEt, Sb-OEt, or Sb-OSCOEt ligands survive, evolving as $\mathrm{EtOH}, \mathrm{EtSH}_{2} \mathrm{Et}_{2} \mathrm{O}$, and $\mathrm{Et}_{2} \mathrm{~S}$ by $250{ }^{\circ} \mathrm{C}$ (Fig. 3, Fig. S4). No FTIR bands were observed in any residue prepared at or above $270{ }^{\circ} \mathrm{C}$ in either atmosphere (not shown), meaning that all carbonaceous matter had mineralized or evolved by that point, in correlation with the results of EGA-MS (Fig. 3, Fig. S4).

The third decomposition step in synthetic air occurred in the range of $250-495{ }^{\circ} \mathrm{C}$, with a mass loss of $1.0 \%$, accompanied by evolution of $\mathrm{SO}_{2}$ (Fig. 3), and a mix of $\mathrm{Sb}_{2} \mathrm{O}_{4}$ and $\mathrm{Sb}_{2} \mathrm{O}_{3}$ as the final product (Table 3). As seen in Fig. 6 b, at $350{ }^{\circ} \mathrm{C}$ in air the gray residue contained at least one sulfate of antimony $\left(\mathrm{Sb}_{2}\left(\mathrm{~S}_{2} \mathrm{O}_{7}\right)_{3}\right)$ in addition to $\mathrm{Sb}_{2} \mathrm{~S}_{3}$, and $\mathrm{Sb}_{2} \mathrm{O}_{4}$ (cervantite), indicating that in the third decomposition step, any remaining $\mathrm{Sb}_{2} \mathrm{~S}_{3}$ is first oxidized to a mixture of $\mathrm{Sb}_{2}\left(\mathrm{~S}_{\mathrm{n}} \mathrm{O}_{3 \mathrm{n}+1}\right)_{3}(n=1 ; 2 ; 3 ; 4)$, e.g., $\mathrm{Sb}_{2}\left(\mathrm{~S}_{2} \mathrm{O}_{7}\right)_{3}$, ICDD 1-070-2198, and $\mathrm{Sb}_{2}\left(\mathrm{SO}_{4}\right)_{2}\left(\mathrm{~S}_{2} \mathrm{O}_{7}\right), 1-083-2537$, then to $\mathrm{Sb}_{2} \mathrm{O}_{3}$, and finally to $\mathrm{Sb}_{2} \mathrm{O}_{4}$ with vigorous exothermic evolution of $\mathrm{SO}_{2}$. Therefore, the formation of sulfates above $300{ }^{\circ} \mathrm{C}$ in the third decomposition step in air initially caused a slight mass gain that was masked by the net mass loss of $2.6 \%$ from the energetic $\mathrm{SO}_{2}$ evolution. The oxidation rate and oxidation product of $\mathrm{Sb}_{2} \mathrm{~S}_{3}$ at $350-500{ }^{\circ} \mathrm{C}$ is strongly dependent on temperature, and particle size [60], which explains the simultaneous detection of antimony compounds in progressive stages of oxidation in the residue.

In the fourth decomposition step in synthetic air in the range of $495-590{ }^{\circ} \mathrm{C}$, the exothermic mass loss at $570{ }^{\circ} \mathrm{C}$ coupled with evolution of $\mathrm{SO}_{2}$ at $575^{\circ} \mathrm{C}$ is caused by purification of residual sulfate via transition of senarmontite$\mathrm{Sb}_{2} \mathrm{O}_{3}$ into valentinite- $\mathrm{Sb}_{2} \mathrm{O}_{3}$ at $570{ }^{\circ} \mathrm{C}$ (cf. $570{ }^{\circ} \mathrm{C}$ in [5], $581{ }^{\circ} \mathrm{C}$ in [54]), followed by oxidation into $\mathrm{Sb}_{2} \mathrm{O}_{4}$, as seen by the difference in XRD patterns of residues prepared at $480{ }^{\circ} \mathrm{C}$ (senarmontite- $\mathrm{Sb}_{2} \mathrm{O}_{3} \&$ cervantite- $\mathrm{Sb}_{2} \mathrm{O}_{4}$ ) and $600{ }^{\circ} \mathrm{C}$ (cervantite- $\mathrm{Sb}_{2} \mathrm{O}_{4}$ ) in air (Fig. 6b). The intermediate residue prepared in $\mathrm{N}_{2}$ at $730{ }^{\circ} \mathrm{C}$ was composed of $\mathrm{Sb}_{2} \mathrm{~S}_{3}$ and $\mathrm{Sb}$ (Fig. 6a). The incongruent evaporation of $\mathrm{Sb}_{2} \mathrm{~S}_{3}$ proceeding above its melting point at $550{ }^{\circ} \mathrm{C}$ is complete by $800^{\circ} \mathrm{C}$, which is consistent with results of previous studies [54], where total mass loss of $\mathrm{Sb}_{2} \mathrm{~S}_{3}$ was observed in inert atmosphere.

Similarly to thiourea-metal chloride complexes that we used to deposit $\mathrm{SnS}, \mathrm{ZnS}, \mathrm{CuInS}_{2}, \mathrm{In}_{2} \mathrm{~S}_{3}$, and $\mathrm{Sb}_{2} \mathrm{~S}_{3}$ thin films by spray pyrolysis for photovoltaic applications [11, 20-22, 61-64], SbEX appears to be an excellent singlesource precursor for producing phase pure $\mathrm{Sb}_{2} \mathrm{~S}_{3}$ thin films by spray pyrolysis.

\section{Conclusions}

It was shown that, according to FTIR and NMR, 1, synthesized from KEX and $\mathrm{SbCl}_{3}$ in molar ratio of $\mathrm{Sb} / \mathrm{S}$ of $1 / 3$, contains a coordination complex, wherein three $-\mathrm{S}_{2} \mathrm{COCH}_{2} \mathrm{CH}_{3}$ - ethyl xanthate ligands are coordinated to $\mathrm{Sb}$ atom via $\mathrm{S}$ atoms. According to elemental analysis and quantitative ${ }^{1} \mathrm{H}$ NMR, 1 contains approximately $95 \mathrm{~mol} \%$ of $\mathrm{Sb}\left(\mathrm{S}_{2} \mathrm{COCH}_{2} \mathrm{CH}_{3}\right)_{3}$, and $5 \mathrm{~mol} \%$ of amorphous $\mathrm{Sb}_{2} \mathrm{~S}_{3}$, as identified by Raman.

The thermal decomposition of $\mathbf{1}$ consists of three mass loss steps in argon in the temperature range of $90-800{ }^{\circ} \mathrm{C}$, whereas in synthetic air, four mass loss steps occurred in the temperature range of $90-590{ }^{\circ} \mathrm{C}$ with mass loss of $100 \%$ and $66.8 \%$, respectively. The first and second thermal decomposition steps proceed similarly in argon and synthetic air in the temperature range of $90-170{ }^{\circ} \mathrm{C}$. In argon, amorphous $\mathrm{Sb}_{2} \mathrm{~S}_{3}$ formed as the product of the first decomposition step by $170{ }^{\circ} \mathrm{C}$ alongside a minor amount of possibly antimony monothiocarbonate 
$\mathrm{Sb}\left(\mathrm{CSO}_{2}\right)_{3}, \mathrm{Sb}(\mathrm{OEt})_{3}, \mathrm{Sb}(\mathrm{SEt})_{3}$ or a mixed ligand compound containing these ligands, identified by EGA-MS and FTIR of intermediate decomposition products. In synthetic air, amorphous senarmontite- $\mathrm{Sb}_{2} \mathrm{O}_{3}$ formed by $170{ }^{\circ} \mathrm{C}$ in addition to the aforementioned compounds, as identified by Raman. In the first decomposition step, $\mathrm{CS}_{2}, \mathrm{EtOH}, \mathrm{CO}, \mathrm{CO}_{2}, \mathrm{COS}, \mathrm{H}_{2} \mathrm{O}$, and $\mathrm{SO}_{2}$ evolved as main gases. Evolution of minor gases $\mathrm{EtSH}$, $\mathrm{Et}_{2} \mathrm{~S}, \mathrm{Et}_{2} \mathrm{O}$, and $(\mathrm{EX})_{2}$ was also detected.

Chemical reactions occurring in the first decomposition step in the temperature range of $90-170{ }^{\circ} \mathrm{C}$ were proposed for the first time for SbEX, describing formation of $\mathrm{CS}_{2}$, $\mathrm{COS}, \mathrm{CO}_{2}, \mathrm{EtOH}, \mathrm{EtSH}, \mathrm{Et}_{2} \mathrm{~S}, \mathrm{Et}_{2} \mathrm{O}$, and intermediate decomposition product ligands, e.g., EtS, EtO, and (monothio)carbonyl-based unsubstituted and the respective alkylsubstituted ligands. Furthermore, the results of this study show that the Chugaev elimination reaction is inadequate to describe the thermal decomposition of SbEX.

In the second thermal decomposition step in argon, the solid phase was purified from the remaining ligands, and thereafter $\mathrm{Sb}_{2} \mathrm{~S}_{3}$ crystallized, as confirmed by XRD and Raman. In synthetic air, the solid phase contained amorphous senarmontite- $\mathrm{Sb}_{2} \mathrm{O}_{3}$, as confirmed by XRD and Raman. The evolved gases in the second thermal decomposition step were the same as in the first step, although evolution of $\mathrm{CS}_{2}$ and EtOH had diminished considerably. In argon, the third and final thermal decomposition step began at $590{ }^{\circ} \mathrm{C}$, after melting of $\mathrm{Sb}_{2} \mathrm{~S}_{3}$ at $550{ }^{\circ} \mathrm{C}$, and proceeded apace until total mass loss at $800^{\circ} \mathrm{C}$. In air, the third decomposition step began at $250{ }^{\circ} \mathrm{C}$, and ended at $495^{\circ} \mathrm{C}$ with the formation of cervantite- $\mathrm{Sb}_{2} \mathrm{O}_{4}$, proceeding through formation and oxidation of a mixture of antimony sulfates coupled with vigorous evolution of $\mathrm{SO}_{2}$ (EGA-MS), as shown for the first time for SbEX through solid-phase intermediate decomposition product analysis in this study by XRD and Raman. In the fourth decomposition step in synthetic air, remaining antimony sulfates oxidized into cervantite- $\mathrm{Sb}_{2} \mathrm{O}_{4}$, as confirmed by XRD of the final product remaining at $600{ }^{\circ} \mathrm{C}$, coupled with evolution of $\mathrm{SO}_{2}$ according to EGA-MS. Neither evolution of carbonaceous species, nor any presence in the solid state in either atmosphere in intermediate decomposition products prepared at or above $270{ }^{\circ} \mathrm{C}$ was detected, indicating that the solid state is free of carbon residues.

Results on the thermal decomposition of tris-ethyldithiocarbonato-antimony(III) (1) in inert and oxidative atmospheres yielded valuable data serving as basis for determining the atmosphere and processing temperatures to be used to deposit phase pure $\mathrm{Sb}_{2} \mathrm{~S}_{3}$ thin films. The fact that SbEX allows to deposit $\mathrm{Sb}_{2} \mathrm{~S}_{3}$ at significantly lower temperatures in comparison to other single-source precursors, and is purified from $\mathrm{C}$ containing residues at very low temperatures, makes $\mathrm{SbEX}$ a suitable precursor for depositing phase pure $\mathrm{Sb}_{2} \mathrm{~S}_{3}$ thin films by the spray pyrolysis method.

\section{Electronic Supporting Material}

The electronic Supplementary File contains the tabulated list of tentative FTIR vibrational assignments from the literature used in this study, the Raman spectrum of 1 in the range of $50-3000 \mathrm{~cm}^{-1}$, and the corresponding tabulated list of tentative Raman vibrational assignments from the literature, the powder XRD pattern of 1 , and the corresponding numeric XRD data, the HMBC plot of 1, EGA-MS gas evolution curves of additional gaseous species, and peak centers and proposed assignments of all $\mathrm{m} / \mathrm{z}$ channels used in the EGA-MS.

Supplementary Information The online version contains supplementary material available at https://doi.org/10.1007/s10973-021-10885-1.

Acknowledgements The authors thank Dr. Valdek Mikli from the Laboratory of Optoelectronic Materials Physics at Tallinn University of Technology for EDX measurements. This study was funded by the Estonian Research Council project PRG627 "Antimony chalcogenide thin films for next-generation semitransparent solar cells applicable in electricity producing windows," European Regional Development Fund Centre of Excellence project TK141 (TAR16016EK) "Advanced materials and high-technology devices for energy recuperation systems," and European Regional Development Fund Centre of Excellence project TK134 "Emerging orders in quantum and nanomaterials."

Author contributions All authors contributed to the study conception and design. Material preparation was performed by J.S. Eensalu. Data collection was performed by J.S. Eensalu, K. Tõnsuaadu and J. Adamson. All authors participated in the data analysis. The first draft of the manuscript was written by J.S. Eensalu and all authors commented on previous versions of the manuscript. All authors read and approved the final and the revised manuscript.

Funding This study was funded by the Estonian Research Council project PRG627 "Antimony chalcogenide thin films for next-generation semitransparent solar cells applicable in electricity producing windows," European Regional Development Fund Centre of Excellence project TK141 (TAR16016EK) "Advanced materials and high-technology devices for energy recuperation systems," and European Regional Development Fund Centre of Excellence project TK134 "Emerging orders in quantum and nanomaterials."

Data availability Data and materials are available upon request from the authors.

\section{Declarations}

Conflict of interest The authors declare that they have no conflict of interest.

Open Access This article is licensed under a Creative Commons Attribution 4.0 International License, which permits use, sharing, adaptation, distribution and reproduction in any medium or format, as long as you give appropriate credit to the original author(s) and the source, provide a link to the Creative Commons licence, and indicate if changes were made. The images or other third party material in this article are included in the article's Creative Commons licence, unless indicated otherwise in a credit line to the material. If material is not included in the article's Creative Commons licence and your intended use is not 
permitted by statutory regulation or exceeds the permitted use, you will need to obtain permission directly from the copyright holder. To view a copy of this licence, visit http://creativecommons.org/licenses/by/4.0/.

\section{References}

1. Klochko K. Antimony Data Sheet. In: Mineral commodity summaries. U. S. Geological Survey. 2020. Available from: https:// pubs.usgs.gov/periodicals/mcs2020/mcs2020-antimony.pdf. Accessed 13 May 2020.

2. Apodaca LE. Sulfur Data Sheet. In: Mineral commodity summaries. U. S. Geological Survey; 2020. Available from: https://pubs. usgs.gov/periodicals/mcs2020/mcs2020-sulfur.pdf. Accessed 13 May 2020

3. Alharbi F, Bass JD, Salhi A, Alyamani A, Kim H-C, Miller RD. Abundant non-toxic materials for thin film solar cells: alternative to conventional materials. Renew Energy. 2011;36:2753-8.

4. Greenwood NN, Earnshaw A. Chemistry of the elements. 2nd ed. Oxford: Butterworth-Heinemann; 1997.

5. Thorneycroft WE. Antimony and bismuth. London: Charles Griffin \& Co Ltd; 1936.

6. Rinkevichius V, Mikalkevichius M. Pyroelectric effect in antimony trisulfide single crystals. Sov Phys Solid State USSR. 1967;9:2360

7. Živković Ž, Štrbac N, Živković D, Grujičić D, Boyanov B. Kinetics and mechanism of $\mathrm{Sb}_{2} \mathrm{~S}_{3}$ oxidation process. Thermochim Acta. 2002;383:137-43.

8. Leijtens T, Bush KA, Prasanna R, McGehee MD. Opportunities and challenges for tandem solar cells using metal halide perovskite semiconductors. Nat Energy. 2018;3:828-38.

9. Kondrotas R, Chen C, Tang J. $\mathrm{Sb}_{2} \mathrm{~S}_{3}$ Solar cells. Joule. 2018;2:857-78.

10. Shin HD, Choi S-H. Recent studies of semitransparent solar cells. Coatings. 2018;8:329-58.

11. Eensalu JS, Katerski A, Kärber E, Weinhardt L, Blum M, Heske $C$, et al. Semitransparent $\mathrm{Sb}_{2} \mathrm{~S}_{3}$ thin film solar cells by ultrasonic spray pyrolysis for use in solar windows. Beilstein J Nanotechnol. 2019;10:2396-409.

12. Savadogo O, Mandal KC. Studies on new chemically deposited photoconducting antimony trisulphide thin films. Sol Energ Mat Sol Cells. 1992;26:117-36.

13. Zimmermann E, Pfadler T, Kalb J, Dorman JA, Sommer D, Hahn G, et al. Toward high-efficiency solution-processed planar heterojunction $\mathrm{Sb}_{2} \mathrm{~S}_{3}$ solar cells. Adv Sci (Weinheim, Ger). 2015;2:1500059.

14. Parize R, Cossuet T, Chaix-Pluchery O, Roussel H, Appert E, Consonni V. In situ analysis of the crystallization process of $\mathrm{Sb}_{2} \mathrm{~S}_{3}$ thin films by Raman scattering and X-ray diffraction. Mater Des. 2017;121:1-10.

15. Wedemeyer H, Michels J, Chmielowski R, Bourdais S, Muto T, Sugiura M, et al. Nanocrystalline solar cells with an antimony sulfide solid absorber by atomic layer deposition. Energy Environ Sci. 2013;6:67-71.

16. Kim D-H, Lee S-J, Park MS, Kang J-K, Heo JH, Im SH, et al. Highly reproducible planar $\mathrm{Sb}_{2} \mathrm{~S}_{3}$-sensitized solar cells based on atomic layer deposition. Nanoscale. 2014;6:14549-54.

17. Büttner P, Scheler F, Pointer C, Döhler D, Barr MKS, Koroleva A, et al. Adjusting interfacial chemistry and electronic properties of photovoltaics based on a highly pure $\mathrm{Sb}_{2} \mathrm{~S}_{3}$ absorber by atomic layer deposition. ACS Appl Energy Mater. 2019;2:8747-56.
18. Kaienburg P, Klingebiel B, Kirchartz T. Spin-coated planar $\mathrm{Sb}_{2} \mathrm{~S}_{3}$ hybrid solar cells approaching 5\% efficiency. Beilstein J Nanotechnol. 2018;9:2114-24.

19. Jiang C, Tang R, Wang X, Ju H, Chen G, Chen T. Alkali metals doping for high-performance planar heterojunction $\mathrm{Sb}_{2} \mathrm{~S}_{3}$ solar cells. Solar RRL. 2019;3:1800272.

20. Kriisa M, Krunks M, Oja Acik I, Kärber E, Mikli V. The effect of tartaric acid in the deposition of $\mathrm{Sb}_{2} \mathrm{~S}_{3}$ films by chemical spray pyrolysis. Mater Sci Semicond Process. 2015;40:867-72.

21. Kärber E, Katerski A, Oja Acik I, Mere A, Mikli V, Krunks M. $\mathrm{Sb}_{2} \mathrm{~S}_{3}$ grown by ultrasonic spray pyrolysis and its application in a hybrid solar cell. Beilstein J Nanotechnol. 2016;7:1662-73.

22. Eensalu JS, Katerski A, Kärber E, Oja Acik I, Mere A, Krunks M. Uniform $\mathrm{Sb}_{2} \mathrm{~S}_{3}$ optical coatings by chemical spray method. Beilstein J Nanotechnol. 2019;10:198-210.

23. Deng H, Yuan S, Yang X, Cai F, Hu C, Qiao K, et al. Efficient and stable $\mathrm{TiO}_{2} / \mathrm{Sb}_{2} \mathrm{~S}_{3}$ planar solar cells from absorber crystallization and Se-atmosphere annealing. Mater Today Energy. 2017;3:15-23.

24. Choi YC, Lee DU, Noh JH, Kim EK, Seok SI. Highly improved $\mathrm{Sb}_{2} \mathrm{~S}_{3}$ sensitized-inorganic-organic heterojunction solar cells and quantification of traps by deep-level transient spectroscopy. Adv Funct Mater. 2014;24:3587-92.

25. Patil PS. Versatility of chemical spray pyrolysis technique. Mater Chem Phys. 1999;59:185-98.

26. Krunks M, Leskelä T, Mutikainen I, Niinistö L. A Thermoanalytical study of copper(I) thiocarbamide compounds. J Therm Anal Calorim. 1999;56:479-84.

27. Otto K, Oja Acik I, Tõnsuaadu K, Mere A, Krunks M. Thermoanalytical study of precursors for $\operatorname{In}_{2} \mathrm{~S}_{3}$ thin films deposited by spray pyrolysis. J Therm Anal Calorim. 2011;105:615-23.

28. Oja Acik I, Otto K, Krunks M, Tõnsuaadu K, Mere A. Thermal behaviour of precursors for $\mathrm{CuInS}_{2}$ thin films deposited by spray pyrolysis. J Therm Anal Calorim. 2013;113:1455-65.

29. Krunks M, Madarász J, Leskelä T, Mere A, Niinistö L, Pokol G. Study of zinc thiocarbamide chloride, a single-source precursor for zinc sulfide thin films by spray pyrolysis. J Therm Anal Calorim. 2003;72:497-506.

30. Madarász J, Krunks M, Niinistö L, Pokol G. Evolved gas analysis of dichlorobis(thiourea)zinc(II) by coupled TG-FTIR and TG/ DTA-MS techniques. J Therm Anal Calorim. 2004;78:679-86.

31. Polivtseva S, Oja Acik I, Krunks M, Tõnsuaadu K, Mere A. Thermoanalytical study of precursors for tin sulfide thin films deposited by chemical spray pyrolysis. J Therm Anal Calorim. 2015;121:177-85.

32. Khwaja MA, Cardwell TJ, Magee RJ. Thermal studies on arsenic, antimony and bismuth alkylxanthate complexes. Anal Chim Acta. 1973;64:9-17.

33. Rodriguez-Castro J, Molloy KC, Liu Y, Lai CS, Dong Z, White TJ, et al. Formation of antimony sulfide powders and thin films from single-source antimony precursors. J Mater Chem. 2008;18:5399-405.

34. Vreugdenhil AJ, Brienne SHR, Butler IS, Finch JA, Markwell RD. Infrared spectroscopic determination of the gas-phase thermal decomposition products of metal-ethyldithiocarbonate complexes. Spectrochim Acta, Part A. 1997;53:2139-51.

35. DePuy CH, King RW. Pyrolytic cis eliminations. Chem Rev. 1960;60:431-57.

36. Chakrabarty T, De AK. Liquid-liquid extraction of arsenic(III), antimony(III) and bismuth(III) with potassium ethyl xanthate. Fresenius' J Anal Chem. 1968;242:152-9.

37. Zard SZ. On the trail of xanthates: some new chemistry from an old functional group. Angew Chem, Int Ed Engl. 1997;36:672-85.

38. Talonen P, Sundholm G, Li WH, Floate S, Nichols RJ. A combined in situ infrared spectroscopy and scanning tunnelling 
microscopy study of ethyl xanthate adsorption on $\mathrm{Au}(111)$. Phys Chem Chem Phys. 1999;1:3661-6.

39. Li J, Liu X, Yao J. The enhanced photovoltaic performance of $\mathrm{Sb}_{2} \mathrm{~S}_{3}$ solar cells by thermal decomposition of antimony ethyl xanthate with thiourea doping. Energy Technol (Weinheim, Ger). 2020;8:1900841.

40. Garje SS, Jain VK. Chemistry of arsenic, antimony and bismuth compounds derived from xanthate, dithiocarbamate and phosphorus based ligands. Coord Chem Rev. 2003;236:35-56.

41. Ray A, Sathyanarayana DN, Prasad GD, Patel CC. Infrared spectral assignments of methyl and ethyl xanthato complexes of nickel(II). Spectrochim Acta, Part A. 1973;29:1579-84.

42. Buchmaier C, Glänzer M, Torvisco A, Poelt P, Wewerka K, Kunert $B$, et al. Nickel sulfide thin films and nanocrystals synthesized from nickel xanthate precursors. J Mater Sci. 2017;52:10898-914.

43. Barreca D, Gasparotto A, Maragno C, Seraglia R, Tondello E, Venzo A, et al. Synthesis and characterization of zinc bis $(\mathrm{O}-$ isopropylxanthate) as a single-source chemical vapor deposition precursor for ZnS. Appl Organomet Chem. 2005;19:1002-9.

44. Vigneshwaran M, Ohta T, Iikubo S, Kapil G, Ripolles TS, Ogomi Y, et al. Facile synthesis and characterization of sulfur doped low bandgap bismuth based perovskites by soluble precursor route. Chem Mater. 2016;28:6436-40.

45. Bansal N, O'Mahony FTF, Lutz T, Haque SA. Solution processed polymer-inorganic semiconductor solar cells employing $\mathrm{Sb}_{2} \mathrm{~S}_{3}$ as a light harvesting and electron transporting material. Adv Energy Mater. 2013;3:986-90.

46. Wojdyr M. Fityk: a general-purpose peak fitting program. J Appl Crystallogr. 2010;43:1126-8.

47. NIST chemistry webbook. National Institute of Standards and Technology. https://webbook.nist.gov/chemistry/. Accessed 28 July 2020.

48. Juncal LC, Cozzarín MV, Romano RM. Conformational and spectroscopic study of xanthogen ethyl formates, $\mathrm{ROC}(\mathrm{S}) \mathrm{SC}(\mathrm{O})$ $\mathrm{OCH}_{2} \mathrm{CH}_{3}$. Isolation of $\mathrm{CH}_{3} \mathrm{CH}_{2} \mathrm{OC}(\mathrm{O}) \mathrm{SH}$. Spectrochim Acta, Part A. 2015;139:346-55.

49. Chandra AP, Puskar L, Simpson DJ, Gerson AR. Copper and xanthate adsorption onto pyrite surfaces: implications for mineral separation through flotation. Int J Miner Process. 2012;114-117:16-26.

50. Woods R, Hope GA. Spectroelectrochemical investigations of the interaction of ethyl xanthate with copper, silver and gold: I. FTRaman and NMR spectra of the xanthate compounds. Colloids Surf A. 1998;137:319-28.

51. Gottardi G. The crystal structure of xanthates II Antimonious xanthate. Z Kristallogr Cryst Mater. 1961;115:451-9.

52. Hoskins BF, Tiekink ERT, Winter G. The crystal and molecular structure of O-ethylxanthato-bis(quinolin-8-olato)antimony(III) and a redetermination for tris(O-ethylxanthato)antimony(III). Inorg Chim Acta. 1985;97:217-22.

53. Fulmer GR, Miller AJM, Sherden NH, Gottlieb HE, Nudelman A, Stoltz BM, et al. NMR chemical shifts of trace impurities: common laboratory solvents, organics, and gases in deuterated solvents relevant to the organometallic chemist. Organometallics. 2010;29:2176-9.

54. Padilla R, Ramírez G, Ruiz MC. High-temperature volatilization mechanism of stibnite in nitrogen-oxygen atmospheres. Metall Mater Trans B. 2010;41:1284-92.

55. IR spectrum table $\&$ chart. Merck KGaA. https://www.sigmaaldri ch.com/technical-documents/articles/biology/ir-spectrum-table. html. Accessed 10 Jul 2020.

56. Fisher NG, Dunn JG. Identifying organic foulants on activated carbon from gold processing plants. Miner Eng. 2000;13:1581-8.

57. Fan H-T, Sun W, Jiang B, Wang Q-J, Li D-W, Huang C-C, et al. Adsorption of antimony(III) from aqueous solution by mercaptofunctionalized silica-supported organic-inorganic hybrid sorbent: Mechanism insights. Chem Eng J (Amst, Neth). 2016;286:128-38.

58. Stueber D, Patterson D, Mayne CL, Orendt AM, Grant DM, Parry RW. Carbonates, thiocarbonates, and the corresponding monoalkyl derivatives. 1. Their preparation and isotropic ${ }^{13} \mathrm{C} N M R$ chemical shifts. Inorg Chem. 2001;40:1902-11.

59. Ferm RJ. The chemistry of carbonyl sulfide. Chem Rev. 1957;57:621-40.

60. Padilla R, Aracena A, Ruiz MC. Kinetics of stibnite $\left(\mathrm{Sb}_{2} \mathrm{~S}_{3}\right)$ oxidation at roasting temperatures. J Min Metall Sect B. 2014;50:127-32.

61. Polivtseva S, Katerski A, Kärber E, Oja Acik I, Mere A, Mikli V, Krunks M. Post-deposition treatment of sprayed SnS films. Thin Solid Films. 2017;633:179-84.

62. Dedova T, Krunks M, Gromyko I, Mikli V, Sildos I, Utt K, et al. Effect of $\mathrm{Zn}: \mathrm{S}$ molar ratio in solution on the properties of $\mathrm{ZnS}$ thin films and the formation of $\mathrm{ZnS}$ nanorods by spray pyrolysis. Phys Status Solidi A. 2014;211:514-21.

63. Otto K, Katerski A, Mere A, Volobujeva O, Krunks M. Spray pyrolysis deposition of indium sulphide thin films. Thin Solid Films. 2011;519:3055-60.

64. Krunks M, Mikli V, Bijakina O, Rebane H, Mere A, Varema T, Mellikov E. Composition and structure of $\mathrm{CuInS}_{2}$ films prepared by spray pyrolysis. Thin Solid Films. 2000;361-362:61-4.

Publisher's Note Springer Nature remains neutral with regard to jurisdictional claims in published maps and institutional affiliations. 